Article

\title{
Diagnostic Performance of PD-L1 versus PD-1 Expression in Circulating CD20 Cells in Diffuse Large B-Cell Lymphoma
}

\author{
Manal Mohamed Saber
}

Citation: Saber, M.M. Diagnostic Performance of PD-L1 versus PD-1 Expression in Circulating CD20 Cells in Diffuse Large B-Cell Lymphoma. Antibodies 2022, 11, 15. https:// doi.org/10.3390/antib11010015

Academic Editor: Itai Benhar

Received: 19 October 2021

Accepted: 10 February 2022

Published: 16 February 2022

Publisher's Note: MDPI stays neutral with regard to jurisdictional claims in published maps and institutional affiliations.

Copyright: (c) 2022 by the author. Licensee MDPI, Basel, Switzerland. This article is an open access article distributed under the terms and conditions of the Creative Commons Attribution (CC BY) license (https:// creativecommons.org/licenses/by/ $4.0 /)$.
Clinical Pathology Department, Faculty of Medicine, Minia University, Minia 61519, Egypt; manal.saber@mu.edu.eg; Tel.: +20-106-090-6673

\begin{abstract}
This study aimed to investigate PD-L1 and PD-1 expression in circulating CD20+ cells in diffuse larger B-cell lymphoma (DLBCL) and to evaluate the predictive and diagnostic performance of PD-L1 versus PD-1 expression in circulating CD20+ cells in DLBCL. Percentages of CD20+, PDL1+CD20+, and PD-1+CD20+ cells were measured by flow cytometry in 40 DLBCL blood samples and 19 healthy controls. The DLBCL patient group was subdivided into 20 newly diagnosed patients with no treatment yet and 20 patients that had finished six cycles of CHOP therapy. Percentages of PD-L1+CD20+ and PD-1+CD20+ cells were highly significantly increased in pre-therapy patients in comparison to healthy volunteers $(p<0.001)$. Meanwhile, a significant decrease in percentages of PD-L1+CD20+ and PD-1+CD20+ was observed in post-CHOP therapy patients in comparison to pre-therapy patients $(p<0.001)$. PD-L1+CD20+ cells were significantly decreased in post-therapy patients when compared to normal controls $(p<0.001)$, while not for PD-1+CD20+ cells. A strong significant positive correlation between percentages of PD-L1+CD20+ and PD-1+CD20+ was detected in DLBCL patients $(p<0.001)$. In the pre-therapy group, high PD-L1+CD20+ and PD-1+CD20+ percentages were correlated with serum LDH levels $(p=0.021, p<0.001)$. High percentages of PD-1+CD20+ were found in DLBCL patients with splenomegaly $(p=0.027)$. The results revealed that patients with advanced tumor stages, poor ECOG performance, and non-GCB DLBCL type had increased percentages of PD-L1+CD20+ and PD-1+CD20+ cells. Moreover, PD-L1+CD20+ \% and PD-1+CD20+ \% were significantly increased in DLBCL patients with bone marrow involvement or B symptoms. The superiority of PD-L1+CD20+ over PD-1+CD20+ was more profound in DLBCL prediction [AUC: 1.0] and in discriminating newly diagnosed patients [AUC: 1.0]. The findings suggest that increased PD-L1/PD-1 expression in peripheral CD20 cells may serve as a companion diagnostic marker for DLBCL. Moreover, percentages of PD-L1+CD20+ cells have better diagnostic performance with higher sensitivity and specificity than PD-1+CD20+\%.
\end{abstract}

Keywords: PD-L1; PD-1; CD20; DLBCL

\section{Introduction}

Diffuse large B-cell lymphoma (DLBCL) is the prevalent type of non-Hodgkin lymphoma (NHL), representing about 37\% of NHL patients [1-3]. DLBCL is an aggressive type of lymphoma accompanied by significant heterogeneity in molecular genetics and clinicopathological features [4]. DLBCL is categorized into two types: germinal center B-cell (GCB type) and non-GCB type $[1,5,6]$. The standard protocol treatment for DLBCL is cyclophosphamide, vincristine, doxorubicin, and prednisone, named "CHOP" [7]. Patients who received CHOP therapy had 55.8\% 6 years survival, and those who had R-CHOP had a 74.3\% survival rate [8]. Extensive research to try to help improve outcomes for these patients is ongoing [9].

The CD20 antigen is a 33-37-kDa non-glycosylated phosphoprotein present on the mature B-cell surfaces [10]. CD20 expression begins at the pre-B-cell and continues until its terminal differentiation into plasma cells [11]. CD20 has been assumed to have a role in B-lymphocyte growth, differentiation, signaling of B-cell receptor (BCR), and the 
initiation events of the cell cycle [12,13]. Many studies showed a high level of CD20 in lymphomas, Hodgkin lymphoma (HD), and DLBCL [14-16]. Almost all DLBCL are positive for CD20 [17]. CD20-negative DLBCL is rare [18] and has been reported to have worse outcomes compared to other DLBCL [19-21]. Several reports have demonstrated that CD20-positive DLBCL attained a complete remission rate of about $60 \%$ when treated with CHOP alone [22-25]. CD20 expression in DLBCL cells and HRS cells acted as a guide for the treatment of Hodgkin lymphoma (HD) and DLBCL patients with regimens including chemotherapy and anti-CD20 antibody $[17,26]$. The addition of rituximab (monoclonal antibody against CD20), to cyclophosphamide, doxorubicin, vincristine, and prednisone (CHOP) has improved DLBCL patients' survival [27,28], however, $30-40 \%$ of cases still develop into relapsed/refractory $(R / R)$ disease, suggesting a selective process toward increased resistance $[29,30]$.

Programmed cell death ligand 1 (PD-L1), a 40-kDa inhibitory protein, was known to be engaged in inhibiting immune responses [31,32]. PD-L1 binding to programmed cell death 1 (PD-1) can result in immune evasion of tumors [33]. PD-L1 and PD-1 were found to be present on B lymphocytes [34-36]. PD-1/PD-L1 expression has been reported in DLBCL patients [37-41]. PD-L1/PD-1 blockage elucidated advantageous therapy in B-lymphoma patients $[42,43]$. Previously, it was reported that the immune responses might be regulated through the PD-1/PD-L1 mechanism. This paper investigated PD-1/PDL1 expression in circulating CD20+ cells and found some associations with laboratory and clinicopathological parameters in DLBCL. The study also evaluated the possibility of PD-L1+CD20 and PD-1+CD20+ cells as references for early diagnosis of DLBCL.

\section{Materials and Methods}

\subsection{Patients}

This study included 19 healthy volunteers and 40 patients diagnosed with DLBCL. Patients were selected from Minia Oncology Center. DLBCL diagnosis was confirmed by pathological examinations, immunophenotyping, and radiological analyses. Patient groups were categorized into 20 newly diagnosed DLBCL patients and 20 patients who had received 6 cycles of $\mathrm{CHOP}$ (cyclophosphamide, doxorubicin, oncovin, prednisone) treatment [44]. DLBCL diagnosis was confirmed by immunophenotyping and histopathology. Healthy controls were matched for age and sex. Written consent was obtained from every subject.

\subsection{Clinical Criteria and Laboratory Samples Collection}

Lymph node biopsy, bone marrow aspiration, and full clinical examination were performed to define the type, stage, and clinical evaluation of DLBCL. According to WHO classifications, three experienced pathologists validated DLBCL pathological specimens [45]. DLBCL classification into GCB and non-GCB types were performed by using the histomorphological data [45], followed by the application of Han's Algorithm [46]. Immunophenotyping of DLBCL was assessed using a flow cytometer. Pelviabdominal ultrasound and X-ray were performed for DLBCL patients to identify extramedullary involvement. DLBCL evaluation was performed regarding the Eastern Cooperative Oncology Group scale [47]. DLBCL staging was performed using the Ann Arbor system through positron emission tomography scans or computed tomography [48]. The patients who had incomplete clinical or pathological data were not involved in the study. Healthy volunteers who had chronic infections or autoimmune diseases were excluded. On a sterile K3EDTA tube, $2 \mathrm{~mL}$ of blood were used for the determination of flow cytometric analysis and complete blood count (CBC). Furthermore, on a plain tube, $4 \mathrm{~mL}$ of blood were centrifuged, and the expressed serum was used for the determination of blood glucose levels, LDH, blood urea, and liver functions tests (total bilirubin, ALT, AST, and serum albumin). 


\subsection{Antibodies}

PD-L1, PD-1, and CD20 expression was determined using Flow Cytometry analysis with commercially available, validated PD-L1 antibody: 29E.2A3, monoclonal antibody (BioLegend; San Diego, CA, USA, catalog No. 309706) [49,50], PD-1 antibody, EH12.2H7, monoclonal antibody (BioLegend; catalog No. 329906) [51,52], and CD20, 2H7, monoclonal antibody (BioLegend; catalog No. 302304) [53,54]. Each antibody was validated for flow cytometric analysis by proving expression by blocking, immunohistochemistry (IHC), and immunoprecipitation [49-54].

\subsection{Flow Cytometry Analysis}

Identification of PD-L1+CD20+ \% and PD-1+CD20+ \% was assessed. Incubation of peripheral blood sample was performed with isotype-matched control or monoclonal antibodies. For each sample, 3 tubes were labeled, one tube for phycoerythrin (PE) conjugated anti-CD 274, fluorescein isothiocyanate (FITC)-conjugated anti-CD20, one tube for PE-conjugated anti-CD 279, FITC-conjugated anti-CD20, and the other tube was used for negative isotypic control. All antibodies were purchased from BioLegend (San Diego, CA, USA). Briefly, $5 \mu \mathrm{L}$ of antibodies were added to $100 \mu \mathrm{L}$ of peripheral blood and were incubated for 20 minutes in the dark at room temperature. Then, $2 \mathrm{~mL}$ red cell lysis buffer was added, vortexed, and incubated for 15 minutes in the dark at room temperature. Sample centrifugation was performed for about five minutes at $1200 \mathrm{rpm}$, and the supernatant was removed. Subsequently, $1 \mathrm{~mL}$ of washing phosphate-buffered saline (PBS) solution was added to every tube, mixed, and centrifuged at $1200 \mathrm{rpm}$ for five minutes and the supernatant was removed. Then, $300 \mu \mathrm{L}$ PBS was added to the cells to resuspend them for flow cytometry analysis. BD-FACS FLOW (Argon laser, BD Biosciences, San Jose, CA, USA) was used for cells analysis using the Cell Quest Program. The lymphocyte gating was assessed according to the forward scatter vs. side scatter (FSC/SSC) plot. CD20+ \%, PD-L1+CD20+ \%, and PD-1+CD20+ \% cells were assessed.

\subsection{Laboratory Methods}

CBC was analyzed by using a Sysmex KX-21N (TAO Medical incorporation, Chuo-ku, Kobe, Japan) automated cell analyzer. Blood urea, creatinine, alanine aminotransferase (ALT), total bilirubin, LDH, blood glucose levels, albumin, and aspartate aminotransferase (AST) were analyzed by using the auto-analyzer clinical chemistry system (Schiaparelli Biosystem INC, Fairfield City, NJ, USA).

\subsection{Statistics}

Data analyses were undertaken using the SPSS program (SPSS-25, Chicago, IL, USA). Data were expressed by the interquartile range (IQR) and median. Mann-Whitney test was performed for data analysis of non-parametric quantitative data between two groups. For non-parametric quantitative results among more than two groups, the Kruskal Wallis analysis was used followed by pairwise comparisons between every two groups using Bonferroni correction. The Chi-square analysis was used for qualitative data between the two groups (if up to $20 \%$ of cells have an expected count less than 5). The Fisher exact test was performed for qualitative data between the two groups (if $>20 \%$ of cells have expected count less than 5), and for qualitative data between more than two groups and between every two groups. The ROC curve was assessed for data analysis. The association between two continuous variables was determined using Pearson's correlation coefficient, while Spearman's correlation coefficient was determined for the association between qualitative ordinal and continuous variables. Significant differences are identified by an asterisk $\left(^{*}\right)$ $(p<0.05)$. Highly significant differences are identified by an asterisk $\left.{ }^{* *}\right)(p<0.001)$. 


\section{Results}

\subsection{Patients' Characteristics}

Characteristics of 40 DLBCL patients (20 male, 20 female) and 19 healthy volunteers are illustrated in Table 1. DLBCL patients had a median age of 46.5 years (the range: $34-55.8$ ). The age and gender of the patients were matched with that of the healthy controls. No significant difference was observed between controls and DLBCL patients regarding their gender and ages $(p>0.05)$. A highly statistically significant difference between patients and controls regarding hepatomegaly and splenomegaly was observed $(p<0.001)$. Of all 40 DLBCL patients, 20 newly diagnosed DLBCL patients and 20 patients had finished CHOP therapy.

Table 1. The comparison between normal controls and DLBCL patients regarding demographic and clinical data.

\begin{tabular}{|c|c|c|c|c|}
\hline \multirow{2}{*}{ KERRYPNX } & & Control & DLBCL & \multirow{2}{*}{$p$-Value } \\
\hline & & $N=19$ & $N=40$ & \\
\hline Age & Median & 45 & 46.5 & 0.955 \\
\hline \multirow[b]{2}{*}{ Sex } & $\begin{array}{c}\text { IQR } \\
\text { Male }\end{array}$ & $\begin{array}{c}(30-57) \\
9(47.4 \%)\end{array}$ & $\begin{array}{l}(34-55.8) \\
20(50 \%)\end{array}$ & \multirow[b]{2}{*}{0.850} \\
\hline & Female & $10(52.6 \%)$ & $20(50 \%)$ & \\
\hline \multirow{2}{*}{ Hepatomegaly } & No & $19(100 \%)$ & $20(50 \%)$ & \multirow{2}{*}{$<0.001$ ** } \\
\hline & Yes & $0(0 \%)$ & $20(50 \%)$ & \\
\hline \multirow{2}{*}{ Splenomegaly } & No & $19(100 \%)$ & $24(60 \%)$ & \multirow{4}{*}{$<0.001 * *$} \\
\hline & Yes & $0(0 \%)$ & $16(40 \%)$ & \\
\hline \multirow{2}{*}{ Treatment } & None & & $20(50 \%)$ & \\
\hline & $\mathrm{CHOP}$ & & $20(50 \%)$ & \\
\hline
\end{tabular}

N: Number; IQR: Interquartile range. A Mann-Whitney test was used for quantitative data. The Chi-square test and Fisher exact test were used for qualitative data. High significant differences are identified with asterisks $\left({ }^{* *}\right)$ $(p<0.001)$.

\subsection{PD-L1/PD-1 Expression in Peripheral CD20+ in DLBCL}

To measure PD-L1+CD20+ \% and PD-1+CD20+ \%, flow cytometry was employed. Increased PD-L1+CD20+ \% were observed in DLBCL patients compared to healthy volunteers (median 9.5 [range: 6.7-16] \% vs. median 1.0 [range: 0.8-1] \%, $p<0.001$ ). As well, PD-1+CD20+ \% of cells was also significantly increased in patients in comparison to normal volunteers (median 4.1 [range: $0.9-9$ ] \% vs. median 0.7 [range: $0.6-1$ ] \%, $p=0.001$ ) as shown in Table 2.

Table 2. Comparison between normal controls and patients regarding CD20+ \%, PD-L1+CD20+\%, and PD-1+CD20+\%.

\begin{tabular}{ccccc}
\hline & & Control & DLBCL & \multirow{2}{*}{$p$-Value } \\
\cline { 3 - 4 } & & $N=\mathbf{1 9}$ & $\mathbf{N}=\mathbf{4 0}$ & \\
\hline \multirow{2}{*}{ CD20+\% } & Median & 24 & 14.5 & \multirow{2}{*}{0.001 * } \\
& IQR & $(20-25)$ & $(10-22)$ & \\
PDL1+CD20+ \% & Median & 1 & 9.5 & $<0.001$ ** \\
& IQR & $(0.8-1)$ & $(6.7-16)$ & \\
PD1+CD20+\% & Median & 0.7 & 4.1 & $0.001 * *$ \\
& IQR & $(0.6-1)$ & $(0.9-9)$ & \\
\hline
\end{tabular}

N: Number; IQR: Interquartile range. The $p$-values were calculated using Mann Whitney test. Significant differences are identified with asterisks $\left(^{*}\right) .(p<0.001)$. High significant differences are identified with asterisks $\left.{ }^{* *}\right)(p<0.001)$.

PD-L1+CD20+ \% and PD-1+CD20+ \% were then analyzed in 20 pre-therapy patients and 20 post-therapy patients (Figure 1). Newly diagnosed patients had CD20+ percentages ranging from 18.3 to 26.8 with a median of 22 . The range of PD-L1+CD20+ \% is 16-25 with a median of 16 while the percentages of PD- $1+C D 20+$ ranged from 8 to 11 with a median of 
9 (Figure 1, Table 3). PD-L1+CD20+ \% and PD-1+CD20+ \% cells were highly significant in DLBCL patients compared to normal controls $(p<0.001)$. Newly diagnosed patients and controls did not exhibit any significant difference regarding CD20 \% of cells $(p>0.05)$.

Table 3. CD20+ \%, PD-L1+CD20+ \%, and PD-1+CD20+ \% in DLBCL patients and healthy subjects.

\begin{tabular}{|c|c|c|c|c|c|c|c|}
\hline & & Controls (I) & $\begin{array}{l}\text { Pre-Therapy } \\
\text { DLBCL (II) }\end{array}$ & $\begin{array}{l}\text { Post-Therapy } \\
\text { DLBCL (III) }\end{array}$ & $p$ & & \\
\hline & & $N=19$ & $N=\mathbf{2 0}$ & $N=20$ & I vs. II & I vs. III & II vs. III \\
\hline $\mathrm{CD} 20+\%$ & $\begin{array}{l}\text { Median } \\
\text { IQR }\end{array}$ & $\begin{array}{c}24 \\
(20-25)\end{array}$ & $\begin{array}{c}22 \\
(18.3-26.8)\end{array}$ & $\begin{array}{c}10 \\
(9.6-11.8)\end{array}$ & 0.525 & $<0.001 *$ & $<0.001^{* *}$ \\
\hline PDL-1+CD20+ \% & $\begin{array}{l}\text { Median } \\
\text { IQR }\end{array}$ & $\begin{array}{c}1 \\
(0.8-1)\end{array}$ & $\begin{array}{c}16 \\
(15-23)\end{array}$ & $\begin{array}{c}6.8 \\
(6-7.9)\end{array}$ & $<0.001^{* *}$ & $<0.001$ * & $<0.001^{* *}$ \\
\hline PD-1+CD20+ \% & $\begin{array}{l}\text { Median } \\
\text { IQR }\end{array}$ & $\begin{array}{c}0.7 \\
(0.6-1)\end{array}$ & $\begin{array}{c}9 \\
(8-11)\end{array}$ & $\begin{array}{c}0.9 \\
(0.6-1)\end{array}$ & $<0.001^{* *}$ & 0.575 & $<0.001^{* *}$ \\
\hline
\end{tabular}

Group I: Healthy volunteers; Group II: Pre-therapy DLBCL patients; Group III: Patients completed 6 CHOP cycles. N: Number; IQR: Interquartile range. Kruskal Wallis test was used for the analysis of data between the three groups followed by pairwise comparisons between every two groups using Bonferroni correction. Significant differences are identified with asterisks $\left(^{*}\right)$. High significant differences are identified by an asterisk $(* *)(p<0.001)$.

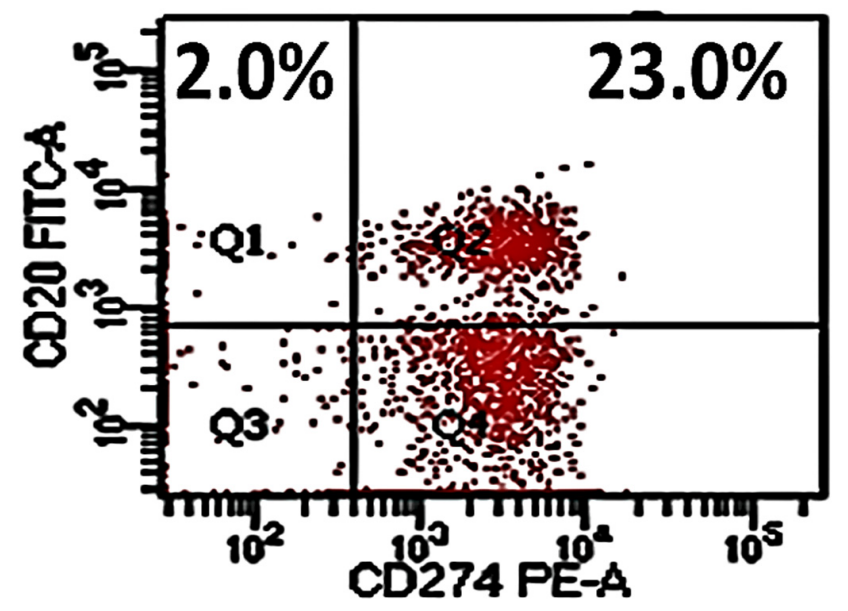

(A)

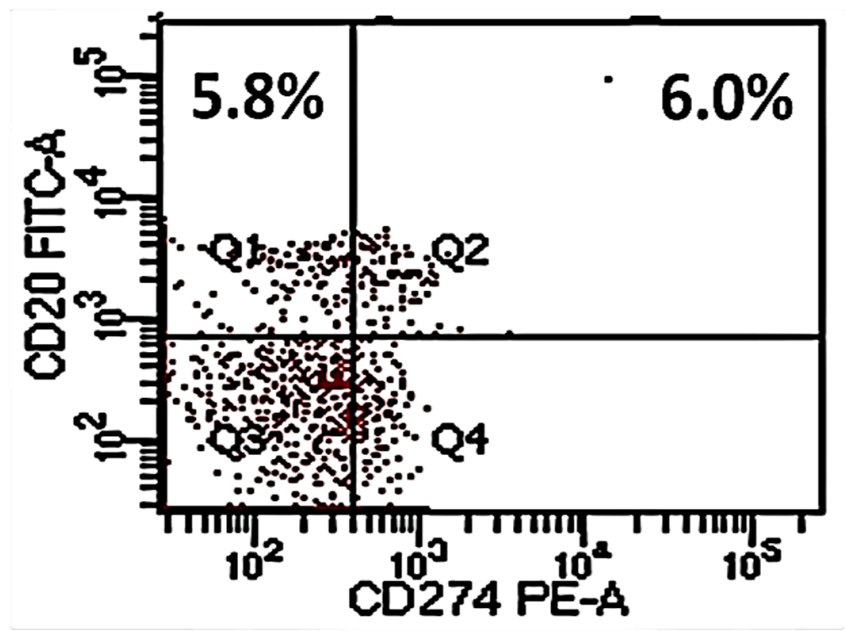

(C)

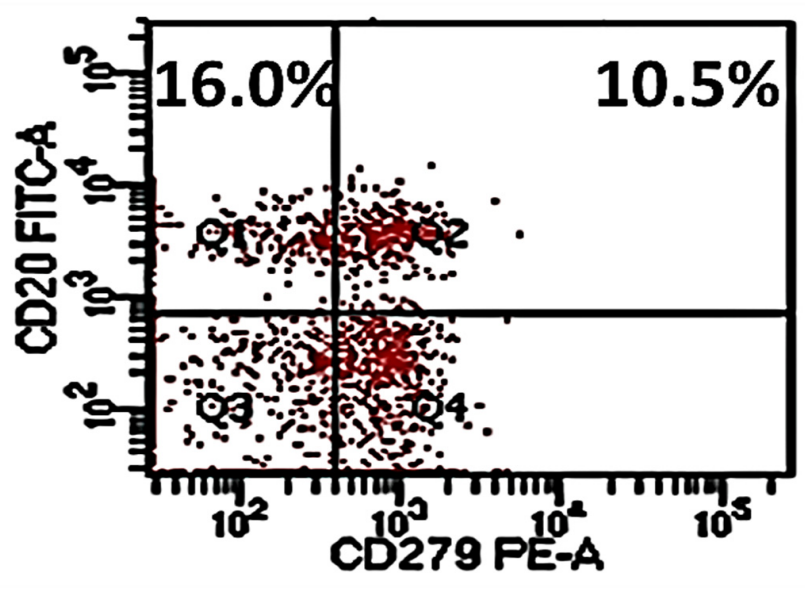

(B)

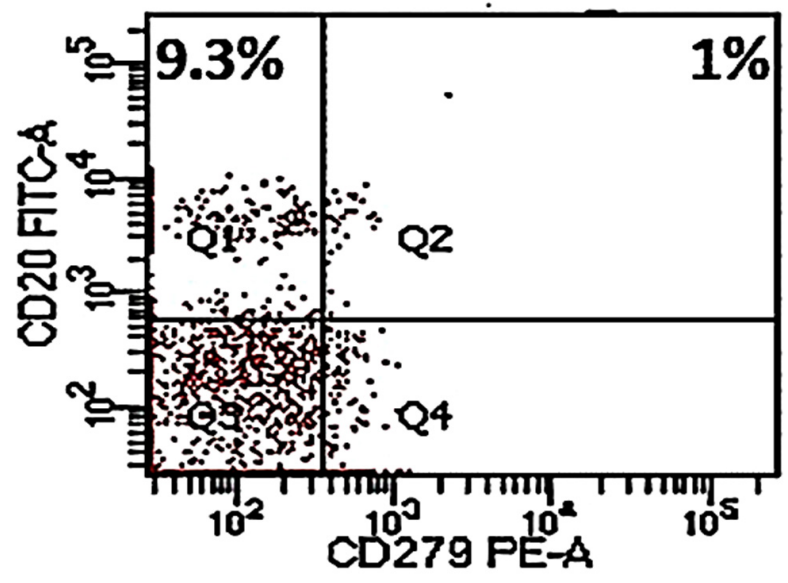

(D)

Figure 1. Cont. 


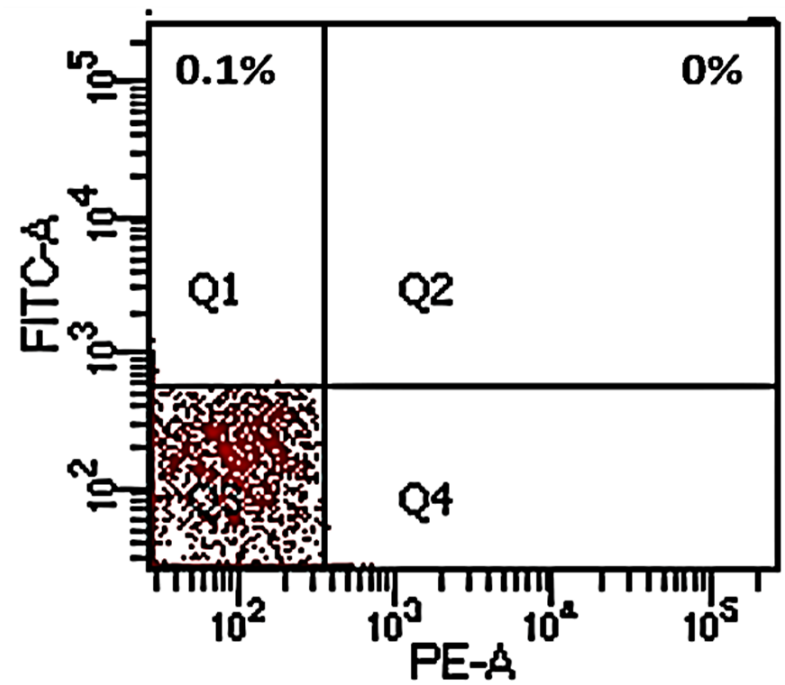

(E)

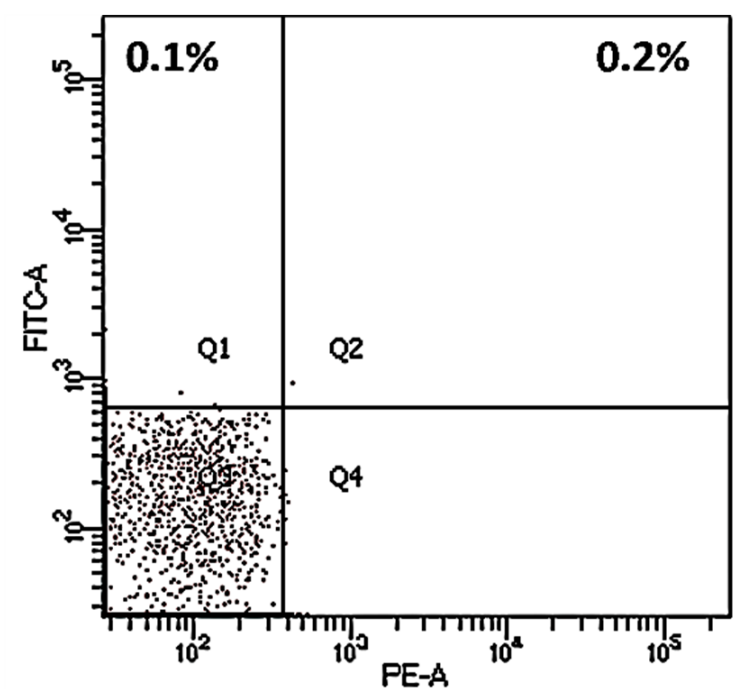

(F)

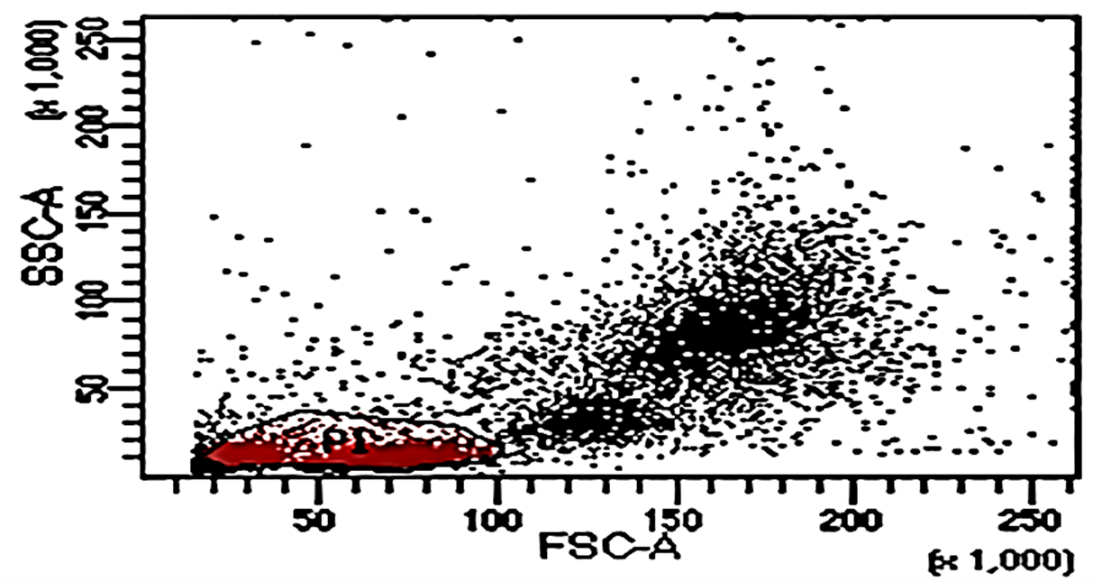

(G)

Figure 1. Flow cytometric plots for measurements of CD20+\%, PD-L1+CD20+\%, and PD- $1+C D 20+\%$ of cells. CD20+ \%, PD-L1+CD20+ \%, and PD-1+CD20+ \% within pre-therapy DLBCL patients (A,B); CD20+ \%, PD-L1+CD20+\%, and PD-1+CD20+\% within post-therapy DLBCL patients (C,D); isotype-matched control for CD20 and PD-L1 (E); isotype-matched control for CD20 and PD-1 (F); gating used to detect cells for analysis $(\mathbf{G})$.

Post-therapy patients had percentages of CD20+ cells ranging from 9.6 to 11.8 with a median of 10. They also had percentages of PD-L1+CD20+ cells ranging from 6 to 7.9 with a median of 6.8. PD-1+CD20+ \% ranged from 0.6 to 1.0 with a median of $0.7(p<0.001)$ (Figure 1, Table 3). Percentages of CD20+ and PD-L1+CD20+ cells were decreased significantly in post-therapy patients in comparison to pre-therapy patients and normal volunteers $(p<0.001)$. PD- $1+C D 20+\%$ was significantly decreased in post-therapy DLBCL patients compared to newly diagnosed ones $(p<0.001)$. Interestingly, no significant difference was detected between post-therapy patients and normal controls regarding PD-1+CD20+ percentages $(p>0.05)$ (Table 3$)$.

In 59 subjects, we found percentages of CD20+ cells $>19$ in 15 healthy controls (78.9\%) in group I, 13 subjects $(65 \%)$ in group II, and 0 subjects $(0 \%)$ in group III. Percentages of PD-L1+CD20+ cells were $>6.8$ in 0 controls $(0 \%)$ in group I, 20 subjects $(100 \%)$ in group II, and 10 subjects (50\%) in group III. PD- $1+$ CD20+ \% of cells was $>1$ in 2 healthy volunteers $(10.5 \%)$ in group I, 20 subjects $(100 \%)$ in group II, and 2 subjects $(10 \%)$ in group III (Table 4$)$. 
Table 4. Low versus high CD20+ \%, PD-L1+CD20+ \% and PD-1+CD20+ \%.

\begin{tabular}{|c|c|c|c|c|c|c|c|}
\hline & & $\begin{array}{l}\text { Control } \\
\text { (I) }\end{array}$ & $\begin{array}{l}\text { Pre-Therapy } \\
\text { DLBCL } \\
\text { (II) }\end{array}$ & $\begin{array}{l}\text { Post-Therapy } \\
\text { DLBCL } \\
\text { (III) }\end{array}$ & $p$ & & \\
\hline & & $N=19$ & $N=20$ & $N=20$ & I vs. II & I vs. III & II vs. III \\
\hline \multirow{2}{*}{$\mathrm{CD} 20+\%$} & Low $(<19)$ & $4(21.1 \%)$ & $7(35 \%)$ & $20(100 \%)$ & \multirow{2}{*}{0.333} & \multirow{2}{*}{$<0.001^{* *}$} & \multirow{2}{*}{$<0.001 * *$} \\
\hline & High (>19) & 15 (78.9\%) & $13(65 \%)$ & $0(0 \%)$ & & & \\
\hline \multirow{2}{*}{ PDL-1+CD20+ \% } & Low $(<6.8)$ & $19(100 \%)$ & $0(0 \%)$ & $10(50 \%)$ & \multirow{2}{*}{$<0.001^{* *}$} & \multirow{2}{*}{$<0.001 * *$} & \multirow{2}{*}{$<0.001^{* *}$} \\
\hline & High $(>6.8)$ & $0(0 \%)$ & $20(100 \%)$ & $10(50 \%)$ & & & \\
\hline \multirow{2}{*}{ PD-1+CD20+ \% } & Low $(<1)$ & $17(89.5 \%)$ & $0(0 \%)$ & $18(90 \%)$ & \multirow{2}{*}{$<0.001^{* *}$} & \multirow{2}{*}{1.0} & \multirow{2}{*}{$<0.001^{* *}$} \\
\hline & $\operatorname{High}(>1)$ & $2(10.5 \%)$ & $20(100 \%)$ & $2(10 \%)$ & & & \\
\hline
\end{tabular}

\subsection{PD-L1/PD-1 Expression and Laboratory-Systemic Data}

In newly diagnosed patients, a significant positive association between CD20+ percentages and total bilirubin was found ( $\mathrm{r}=0.611$ and $p=0.021)$ (Figure 2A). Additionally, CD20+ \% and PD-L1+CD20 $\%$ of cells had a highly significant negative correlation with albumin ( $p=0.018$ and $p=0.026$ ) (Figure 2B,C). The association between PD-L1+CD20+ \% and PD- $1+C D 20+\%$ was further investigated in DLBCL patients (Figure 2D). The analysis identified that PD-L1+CD20+ \% cells were positively associated with the percentages of PD- $1+C D 20+$ cells $(p<0.001)$. No significant associations were detected in post-therapy patients (splenomegaly, hepatomegaly, or laboratory profile).

A strong significant association was found between high CD20+ \%, PD-L1+CD20+ \%, PD- $1+C D 20+\%$, and serum LDH levels $(p=0.002, p=0.021 ; p<0.001)$. Additionally, a significant positive association was identified between high PD-L1+CD20 percentages and random blood sugar $(p=0.020)$. Interestingly, those with splenomegaly had high significant percentages of PD- $1+$ CD20+ cells $(p=0.027)$ (Table 5).

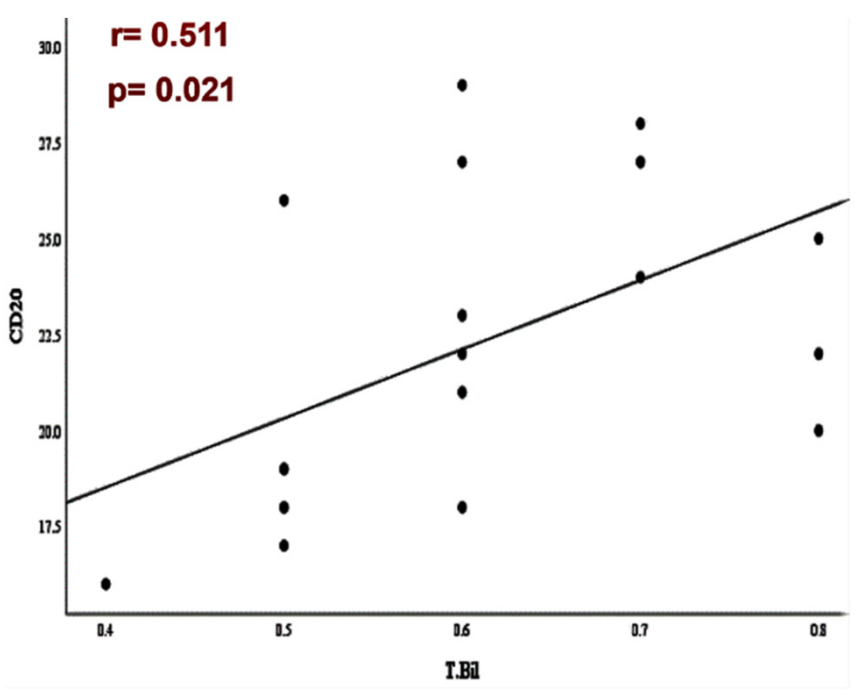

(A)

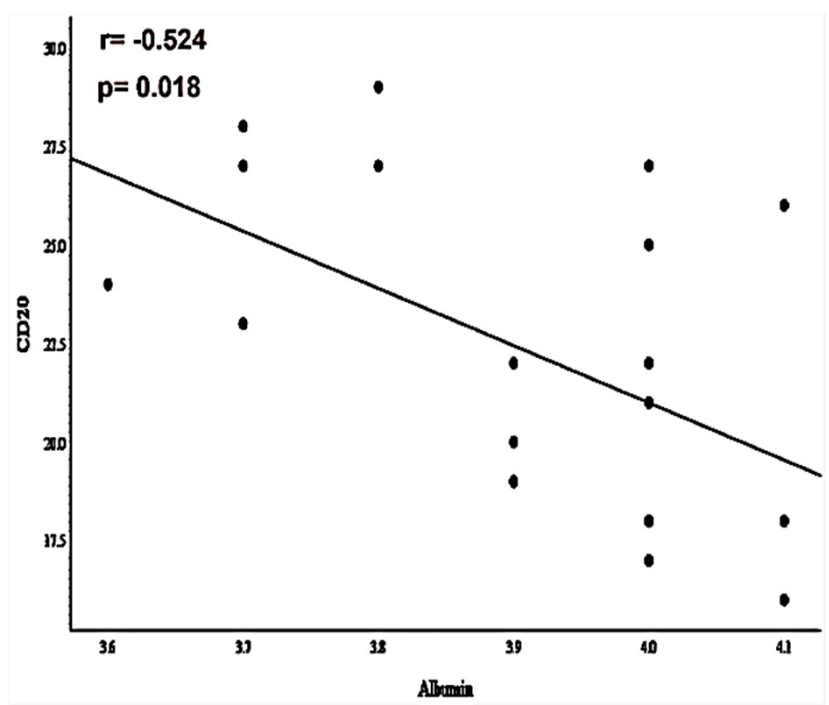

(B)

Figure 2. Cont. 


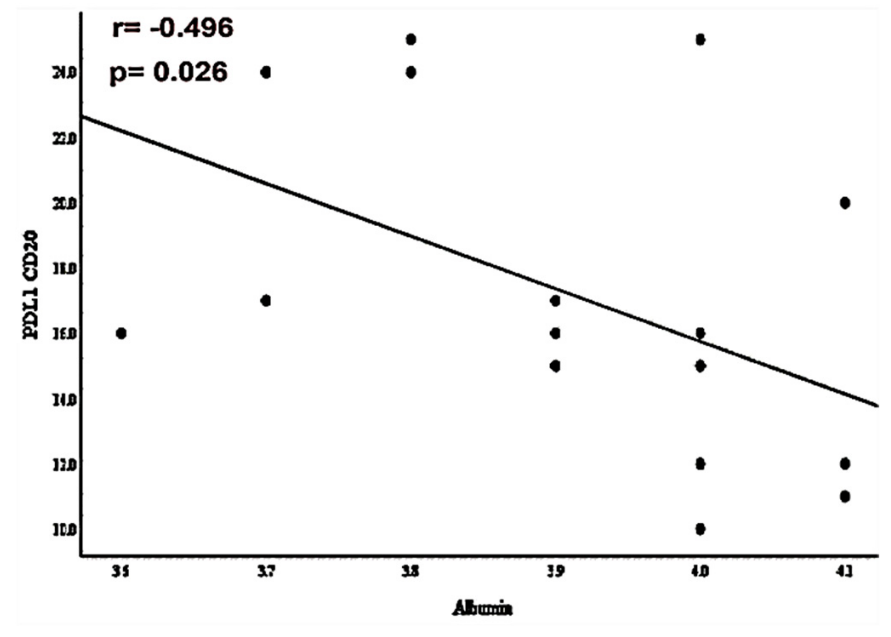

(C)

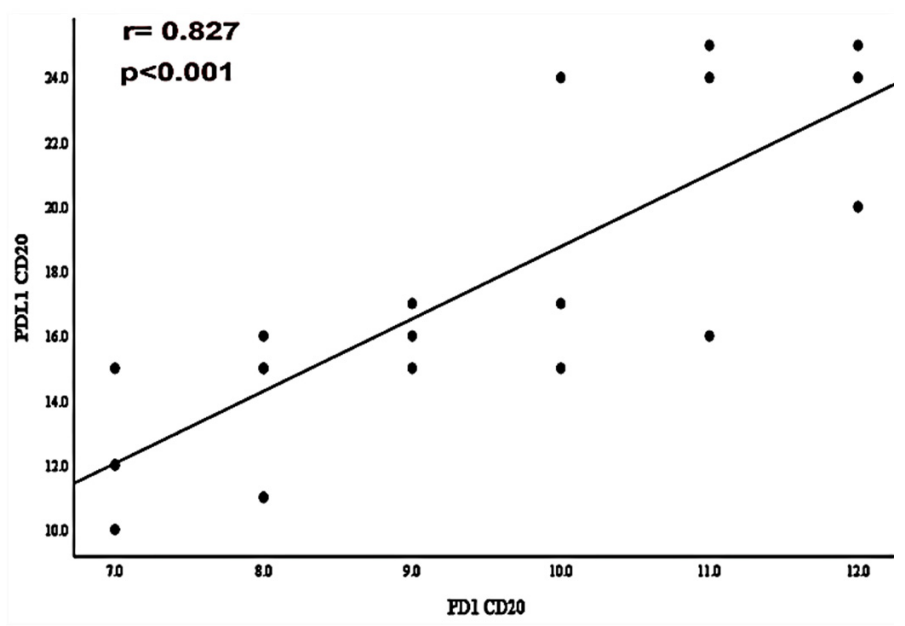

(D)

Figure 2. (A) Diagram illustrating the positive association between percentages of CD20+ cells and total bilirubin levels $(\mathrm{r}=0.511 ; p=0.021)$; (B) diagram illustrating the negative association between percentages of CD20+ cells and serum albumin levels $(\mathrm{r}=-0.524 ; p=0.018) ;(\mathbf{C})$ diagram illustrating the negative association between percentages of PD-L1+CD20+ cells and serum albumin levels $(\mathrm{r}=-0.496 ; p<0.026)$; $(\mathrm{D})$ diagram illustrating the positive correlation between PD-L1+CD20+ \% and PD-1+CD20+ \% $(r=0.827 ; p<0.001)$. Pearson's correlation analysis was used.

Table 5. Correlation of high CD20+ \%, PD-L1+CD20+\%, PD-1+CD20+ \% cells and DLBCL patient disease characteristics.

\begin{tabular}{|c|c|c|c|c|c|c|}
\hline & \multicolumn{2}{|c|}{ High CD20+ \% } & \multicolumn{2}{|c|}{$\begin{array}{c}\text { High } \\
\text { PD-L1+CD20+ \% }\end{array}$} & \multicolumn{2}{|c|}{$\begin{array}{c}\text { High } \\
\text { PD-1+CD20+ \% }\end{array}$} \\
\hline & $\mathbf{r}$ & $p$-Value & $\mathbf{r}$ & $p$-Value & $\mathbf{r}$ & $p$-Value \\
\hline High PD-L1+CD20+ \% ${ }^{(P)}$ & 0.401 & $0.010 *$ & & & & \\
\hline High PD-1+CD20+\% ${ }^{(P)}$ & 0.628 & $<0.001^{* *}$ & 0.638 & $<0.001^{* *}$ & & \\
\hline $\mathrm{L} \mathrm{D} \mathrm{H}^{(\mathrm{P})} \mathrm{U} / \mathrm{L}$ & 0.479 & $0.002 *$ & 0.365 & $0.021 *$ & 0.549 & $<0.001^{* *}$ \\
\hline Random glucose $^{(\mathrm{P})}(\mathrm{mg} / \mathrm{dL})$ & 0.019 & 0.910 & 0.368 & $0.020 *$ & 0.152 & 0.348 \\
\hline Splenomegaly $(\mathrm{S})$ & 0.235 & 0.151 & 0.251 & 0.123 & 0.354 & $0.027 *$ \\
\hline
\end{tabular}

LDH: Lactate Dehydrogenase. ( $\left.{ }^{*} p \leq 0.05\right)$ identifies significant differences). ${ }^{(\mathrm{P})}$ Pearson's correlation; ${ }^{(\mathrm{S})}$ Spearman's correlation. $\left.{ }^{* *} p<0.001\right)$ identifies highly significant differences.

\subsection{Clinicopathological Analysis and PD-L1/PD-1 Expressions in DLBCL}

PD-L1+CD20+ \% and PD-1+CD20+ \% were analyzed in pre-therapy DLBCL patients with or without clinicopathological criteria. As for $\mathrm{B}$ symptoms and bone marrow involvement, PD-L1+CD20+ \% and PD-1+CD20+CD20+\% had a significant increase in DLBCL patients with B symptoms and bone marrow involvement $(p<0.001, p=0.001$, $p<0.001$ and $p=0.001$, Figure 3A-D). Similarly, patients with non-GCB subtypes presented higher PD-L1+CD20+ \% and PD-1+CD20+ \% than those with GCB subtypes ( $p<0.001$ and $p=0.009$, Figure $3 \mathrm{E}, \mathrm{F})$.

Percentages of PD-L1+CD20+ in pre-therapy patients with different stages were investigated. Data revealed that DLBCL patients with stages I and II did not have significant changes in the percentages of cells, whereas DLBCL patients with stages III and IV presented higher PD-L1+CD20+\%, in which stage IV revealed significantly increased percentages of PD-L1+CD20+ cells than stages I and II ( $p=0.001$ ) (Figure 3G). DLBCL patients with stage IV also presented significantly higher percentages of PD-1+CD20+ cells than those with primary stages $(p=0.003$, Figure $3 \mathrm{H})$. Furthermore, patients with poor ECOG performance presented significantly higher PD-L1+CD20+\% and PD-1+CD20+\% than those with satisfactory performance $(p=0.003$ and $p=0.009$, Figure 3I,J). No signifi- 
cant correlation was observed between age or extranodal involvement and these proteins' expression (Supplementary Table S1).

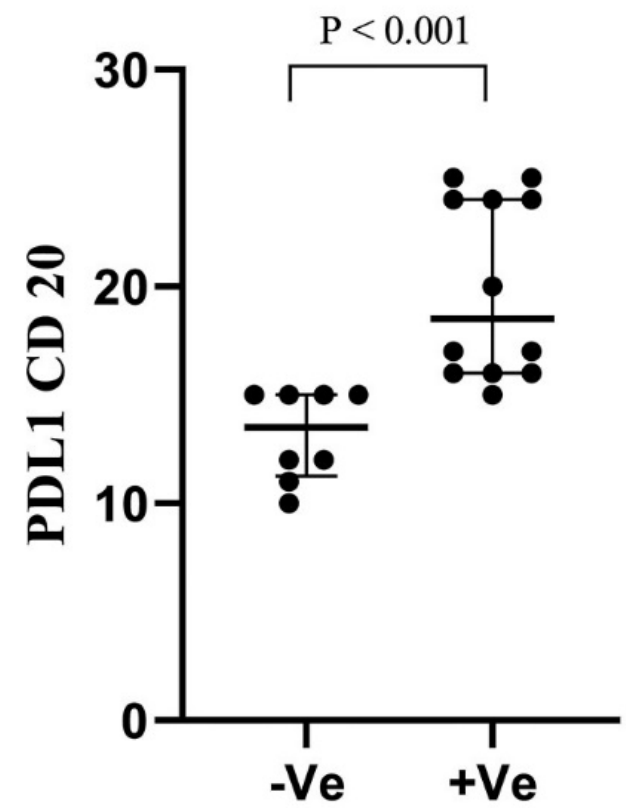

B Symptoms

(A)

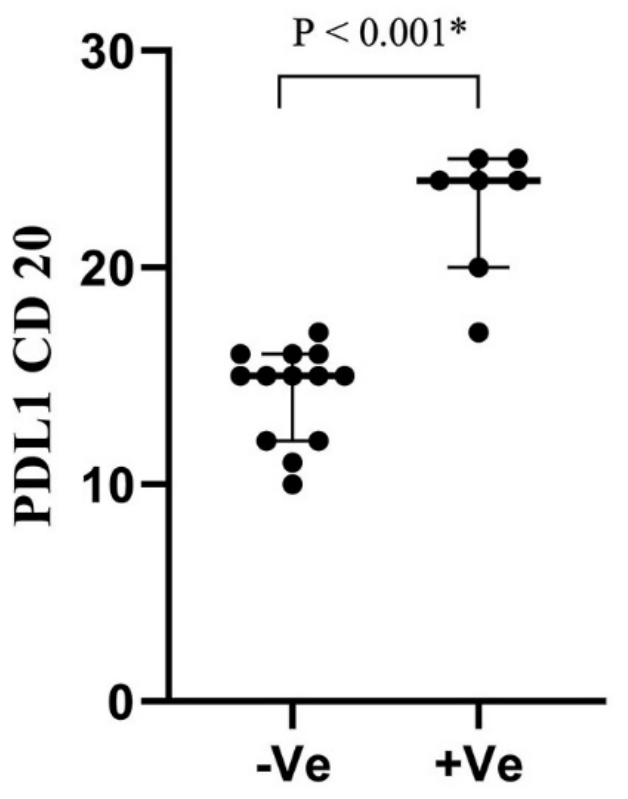

Bone marrow involovment

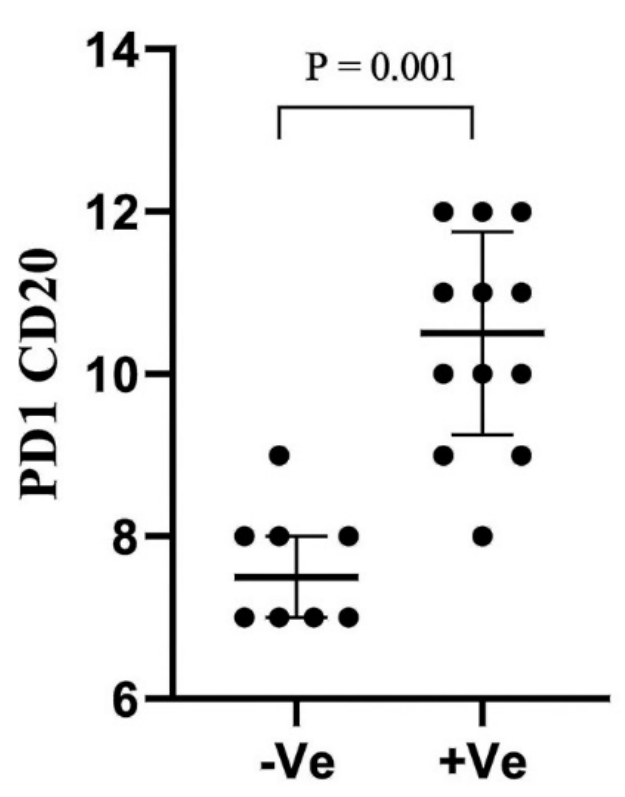

B Symptoms

(B)

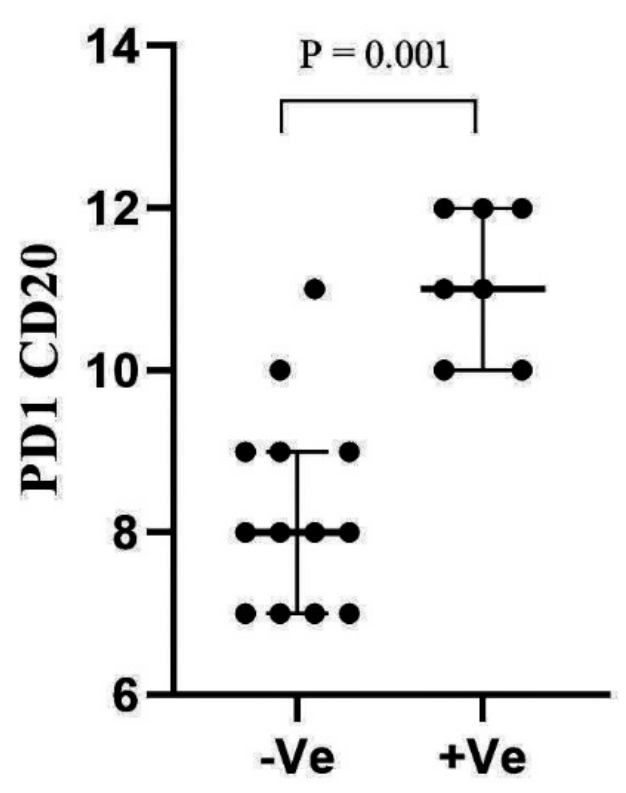

Bone marrow involovment

(C) 


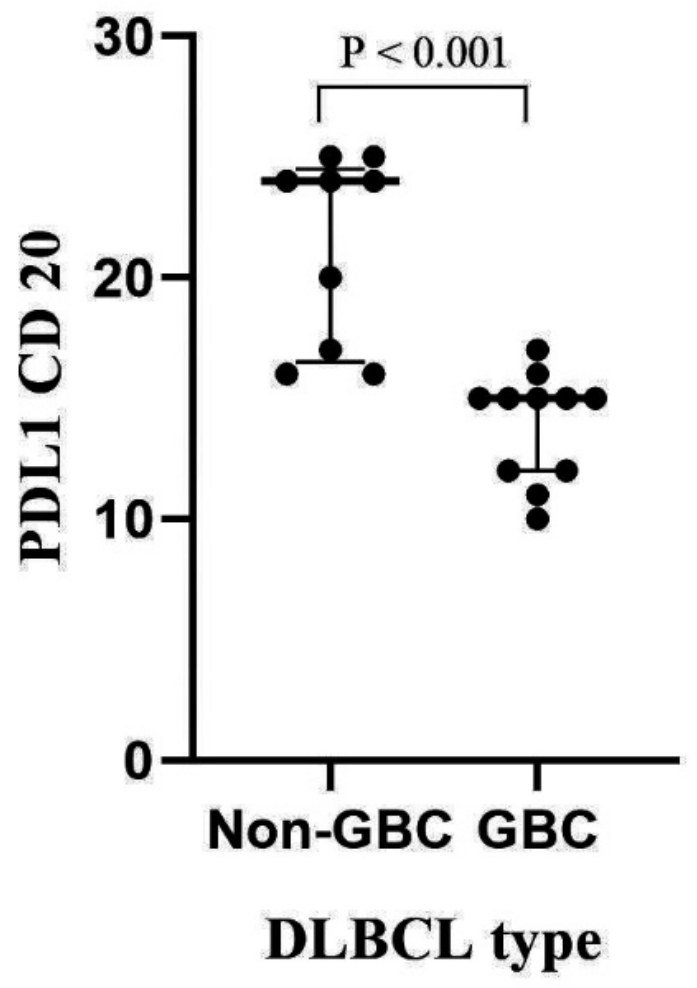

(E)

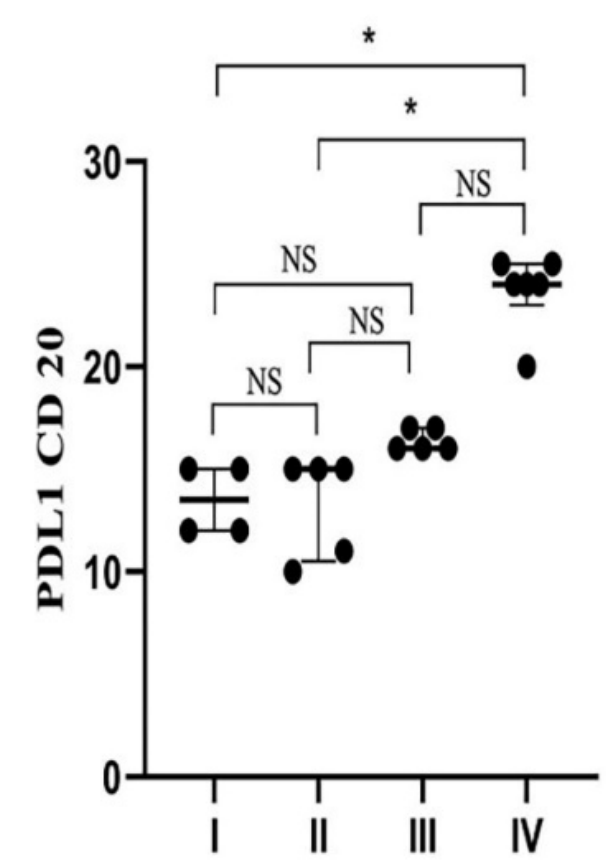

Ann Arbor Stage

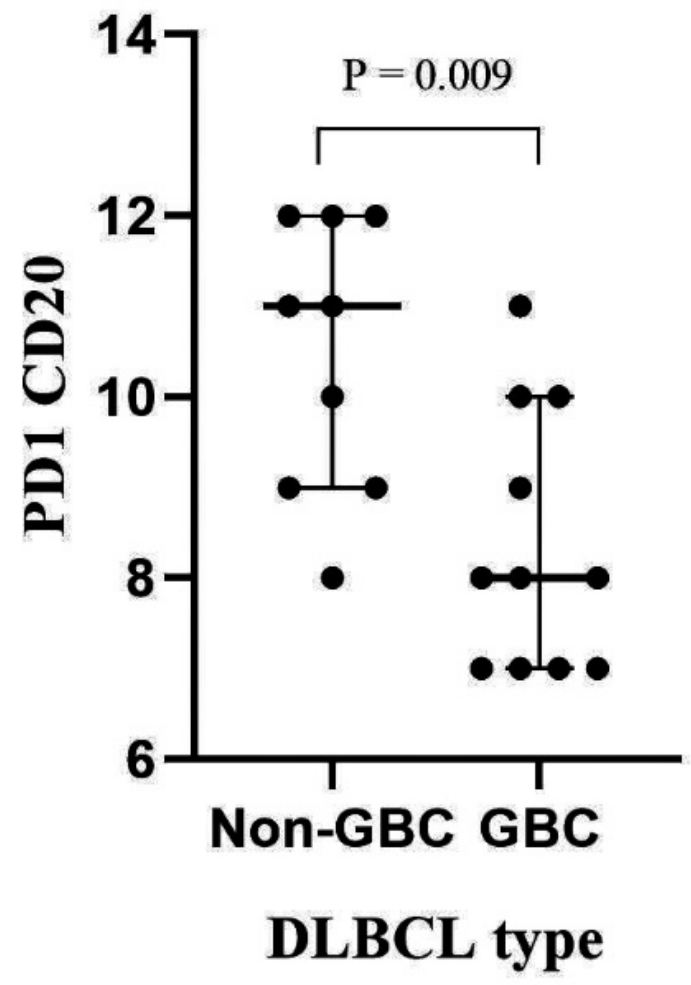

(F)

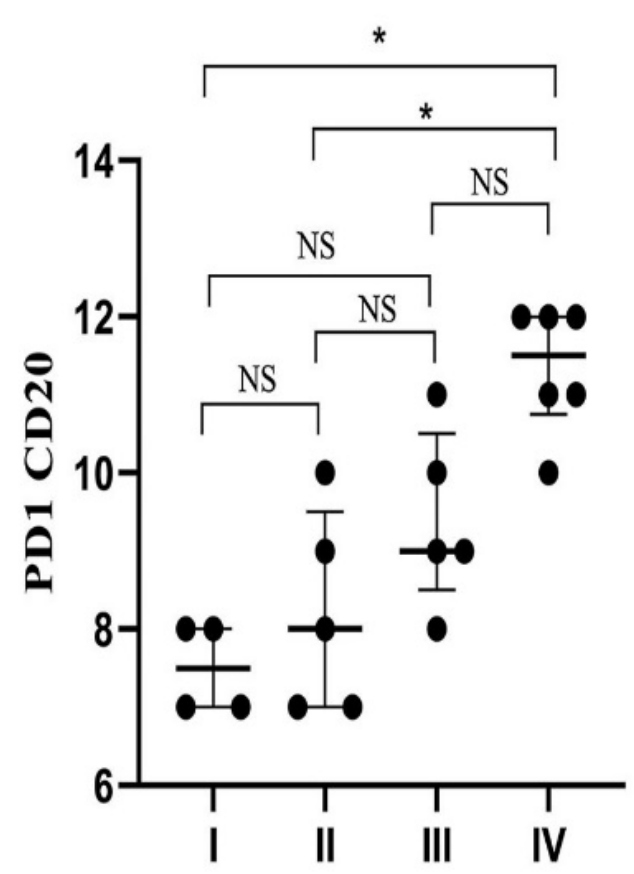

Ann Arbor Stage

Figure 3. Cont. 


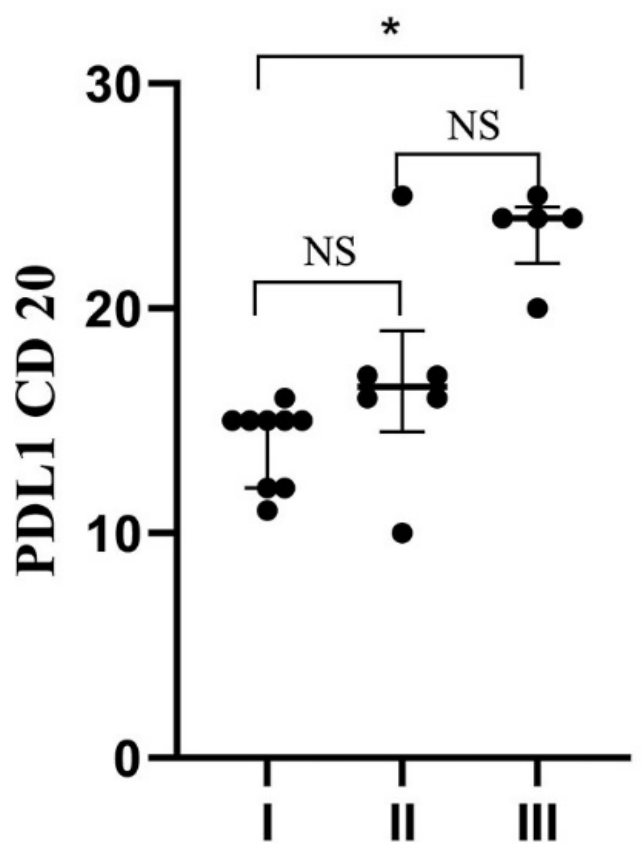

ECOG performance

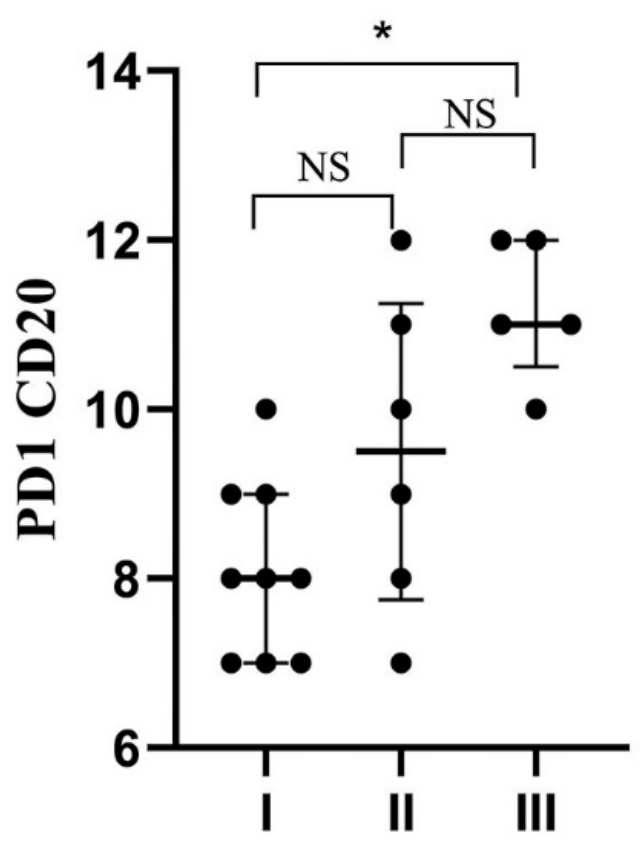

ECOG performance

Figure 3. Percentage of PD-L1+CD20+ and PD-1+CD20+ in pre-therapy DLBCL patients with B symptoms (A,B); bone marrow involvement (C,D); DLBCL type (E,F); Ann Arbor stage (G,H) and ECOG performance $(\mathbf{I}, \mathbf{J})$. Each dot represented one patient. In total, 20 DLBCL patients were involved. NS: not significant; GCB: germinal center B-cell; ECOG: Eastern Cooperative Oncology Group; -ve: negative; +ve: positive. $p$-value is shown. ${ }^{*} p<0.05$.

Additionally, the clinical relevance of these genes in post-therapy DLBCL patients was investigated. The results showed that patients with the GCB type presented lower percentages of PD-L1+CD20+ cells than those with the non-GCB subtype ( $p=0.045$, Figure 4A). Similarly, PD-L1+CD20+ \% cells were significantly lower in stage I than stages III and IV $(p=0.001$, Figure 4B). No significant associations were detected in post-therapy patients regarding other clinicopathological criteria. Furthermore, there was no significant correlation between percentages of PD-1+CD20+ and these criteria (Supplementary Table S2).

\subsection{The Predictive and Diagnostic Efficacies of Circulating PD-L1+CD20+ and PD-1+CD20+ Cells}

The receiver operating curve (ROC) analysis was used to detect the cut-offs with the best predictive value. ROC curves of CD20+\%, PD-L1+CD20+ \%, and PD- $1+$ CD20+ \% for detecting patients with DLBCL from healthy controls were illustrated in Figure 5.

The area under the curve (AUC) of CD20+ \% was 0.780 for predicting patients with DLBCL from patients with normal controls [ $p<0.001]$ (Figure 5A). Additionally, AUC of PD-L1+CD20+ \% was 1.0 for predicting patients with DLBCL from healthy controls $[p<0.001]$, however, PD-1+CD20+ \% AUC was 0.767 for identifying patients with DLBCL from healthy volunteers $(p<0.001)$ (Figure $5 \mathrm{C}, \mathrm{E})$. The sensitivity and specificity of PD$\mathrm{L} 1+\mathrm{CD} 20+\%$ was $100 \%$, while was $75 \%$ and $73.68 \%$ for PD- $1+\mathrm{CD} 20+\%$. The cut-off values of CD20+ \%, PD-L1+CD20+ \% and PD-1+CD20+ \% were $\leq 22,>1.1$ and $>0.8$, respectively.

In newly diagnosed patients, the specificity and sensitivity of PD-L1+CD20+ $\%$ and PD-1+CD20+ $\%$ was $100 \%$, while was $55 \%$ and $63.16 \%$, respectively, for CD20+ $\%$. The discriminative cutoff of CD20+ \% was $\leq 22$, with AUC 0.559 (Figure 5B). The cutoff of 
PD-L1+CD20+ \% was $>1.1$, with an AUC value of $1.0(p<0.001)$ (Figure 5D). The AUC value of PD-1+CD20+ \% was 1.0 with cut-off $>1.2(p<0.001)$ (Figure $5 \mathrm{~F})$.

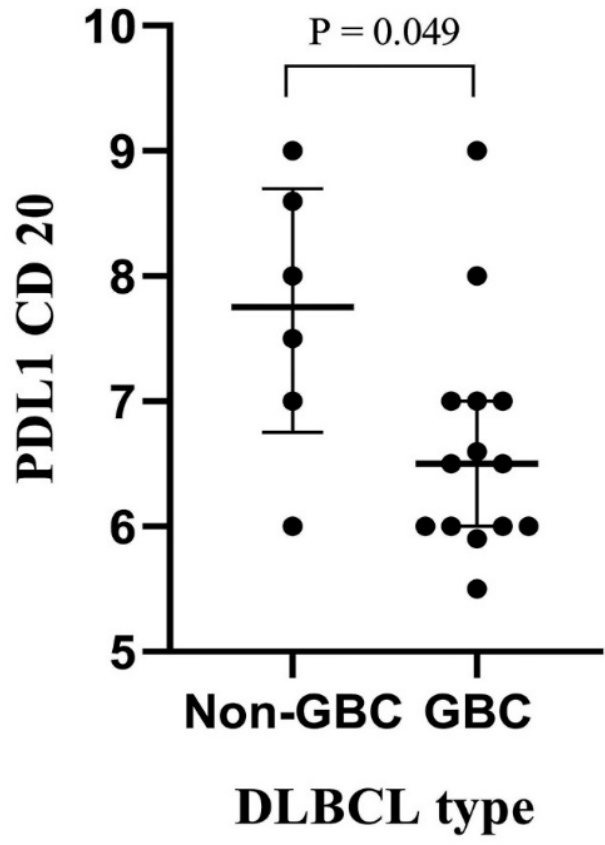

(A)

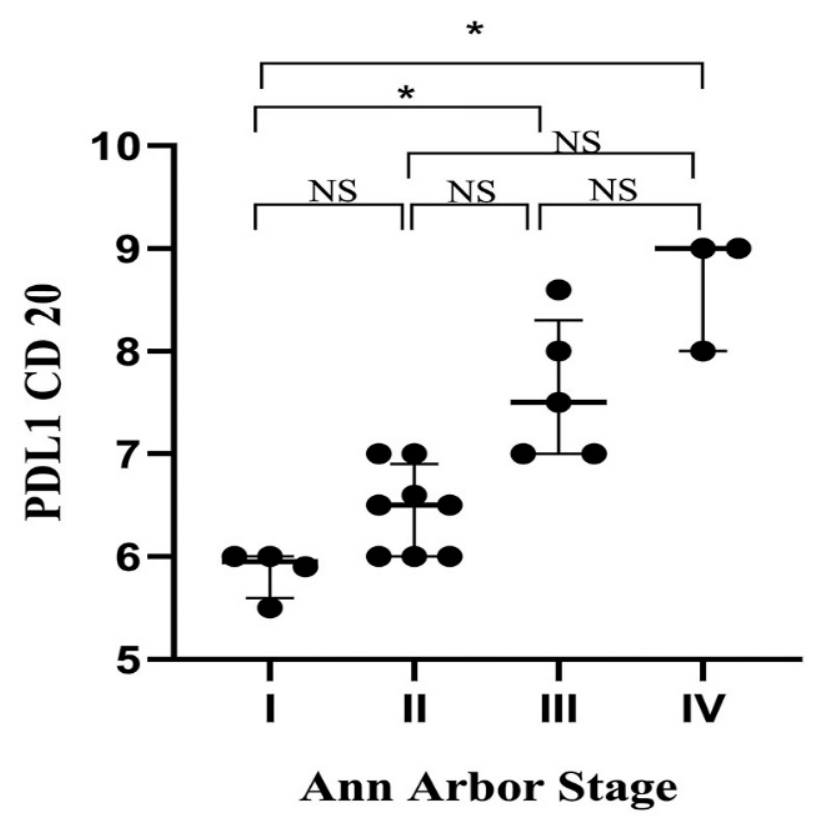

(B)

Figure 4. Percentage of PD-L1+CD20+ in post-therapy DLBCL patients. DLBCL type (A); Ann Arbor stage (B). Each dot represented one patient. In total, 20 DLBCL patients were involved. GCB: germinal center B-cell; NS: not significant. $p$-value is shown. ${ }^{*} p<0.05$.

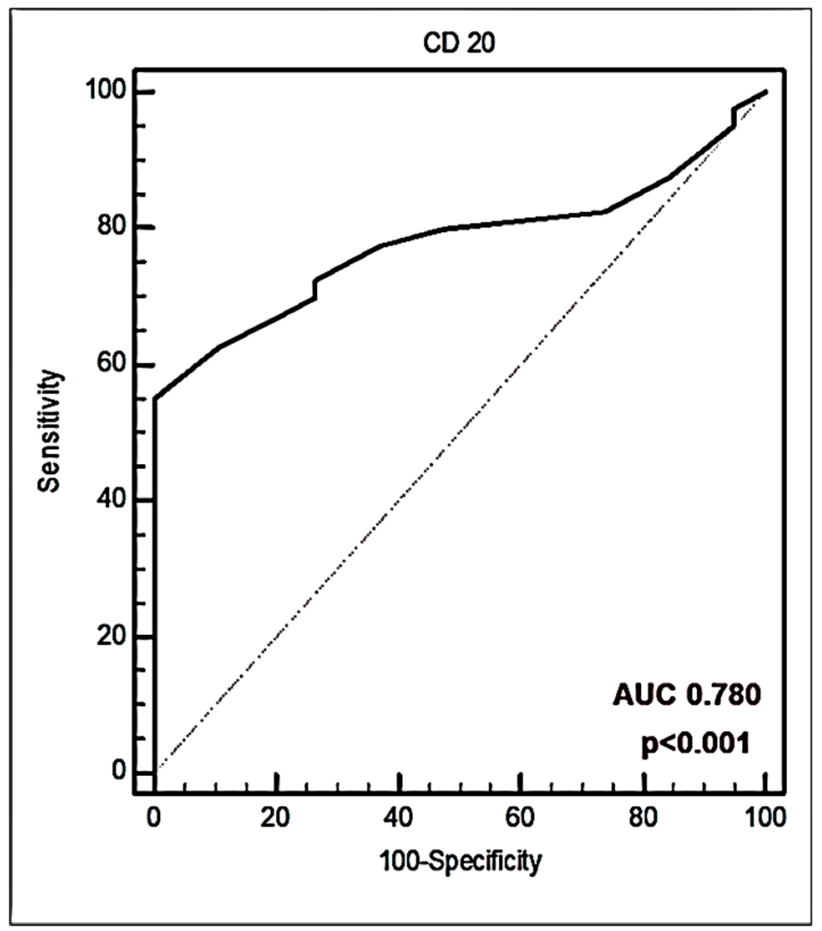

(A)

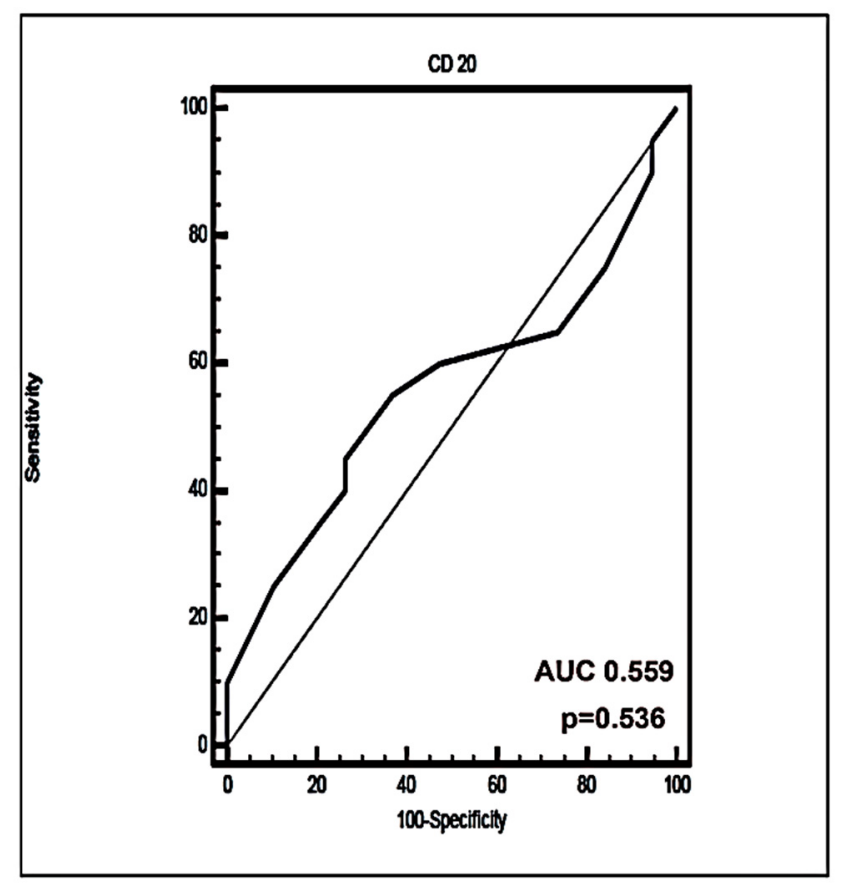

(B)

Figure 5. Cont 


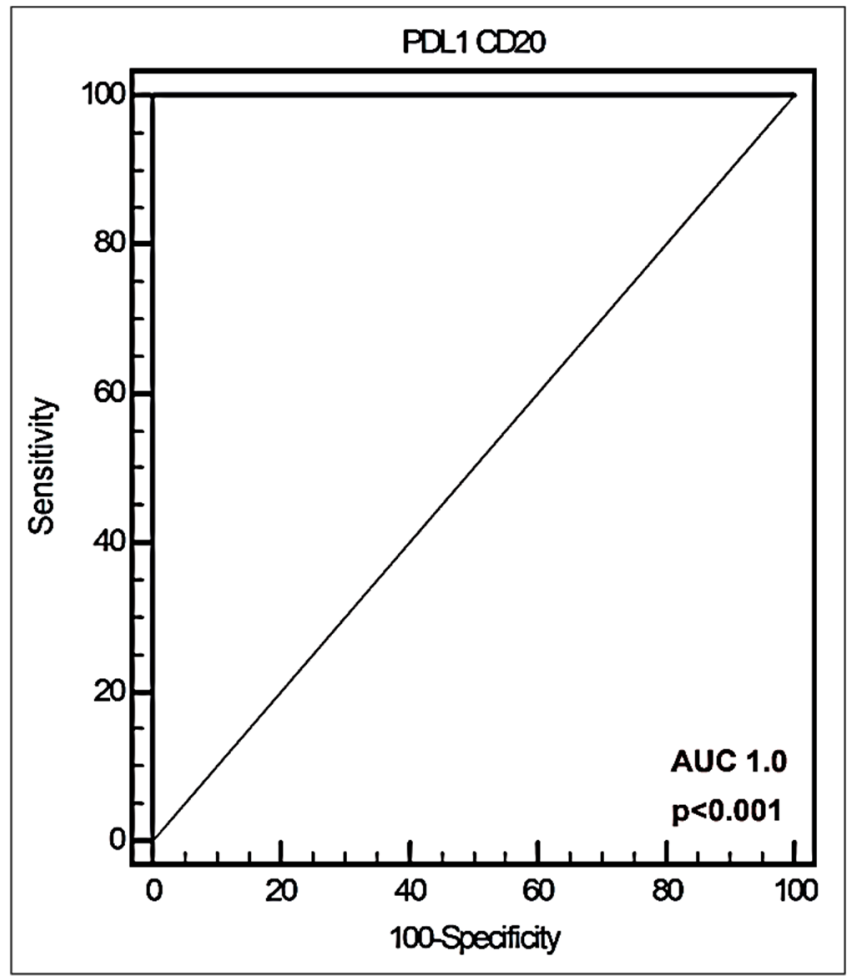

(C)

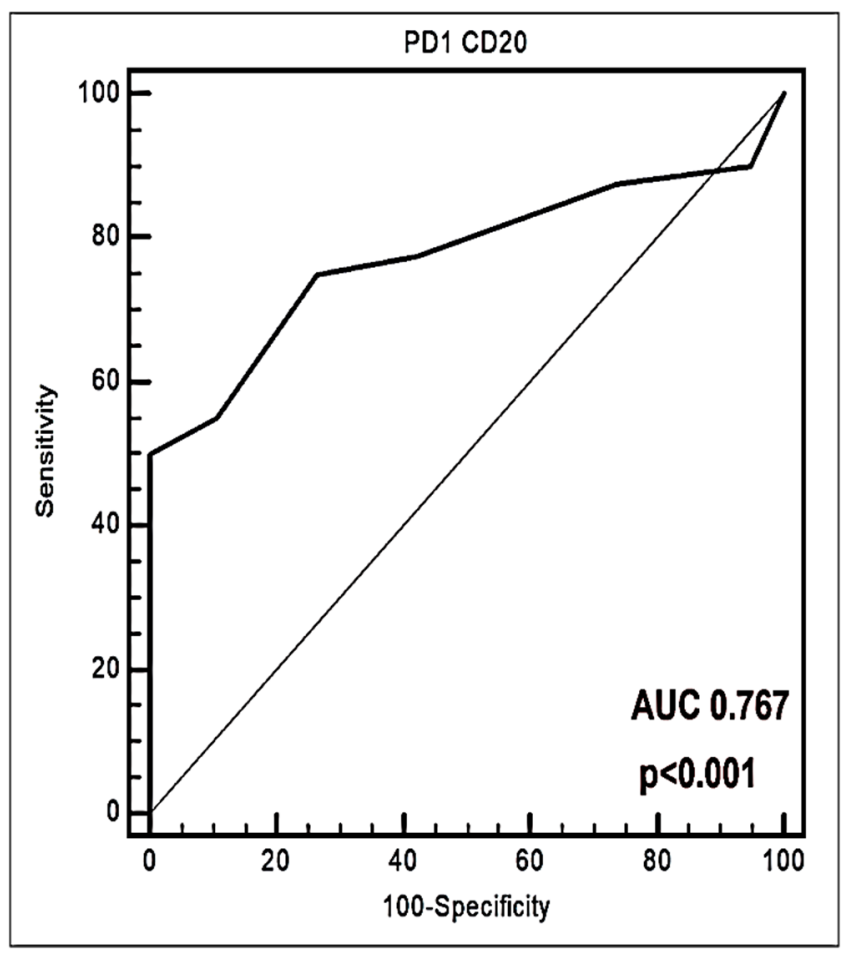

(E)

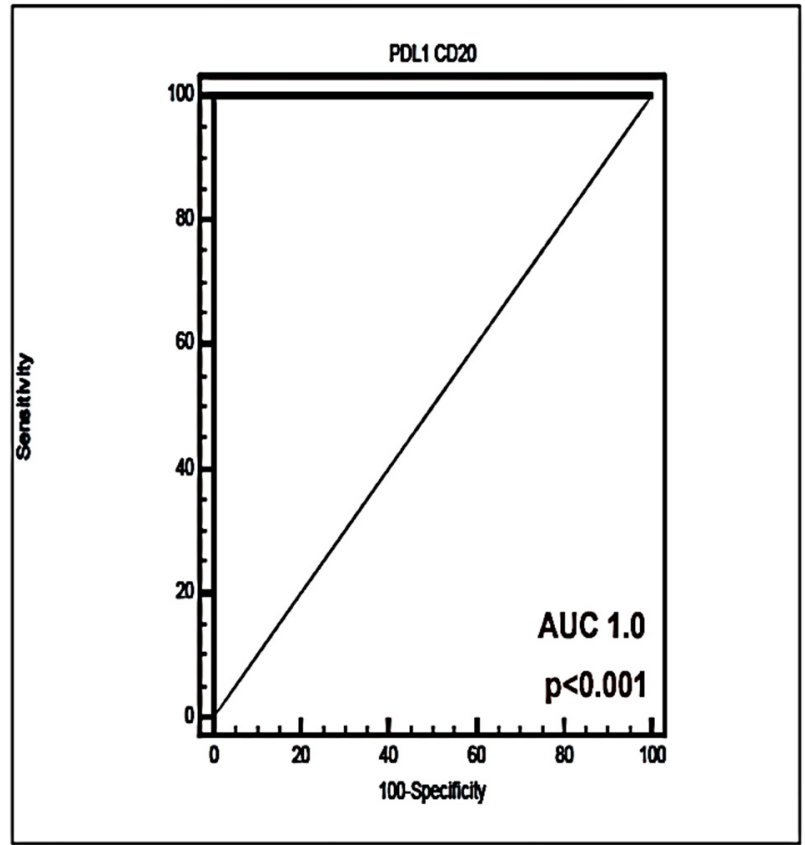

(D)

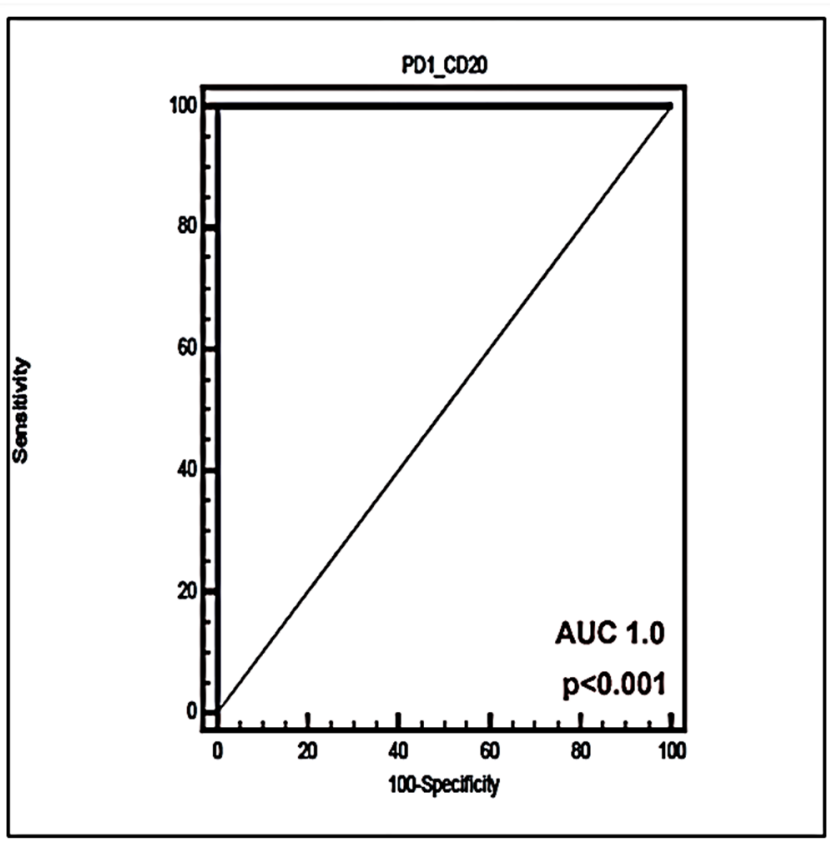

$(\mathbf{F})$

Figure 5. Receiver operating characteristic (ROC) curve performance for prediction and diagnosis of DLBCL. (A,B) ROC curves of percentages of CD20+ cells. (C,D) ROC curves of percentages of PD-L1+CD20+ cells. (E,F) ROC curves of percentages of PD-1+CD20+ cells (\%). 


\section{Discussion}

DLBCL is an aggressive NHL with a standard treatment that depends on CHOP-like cytotoxic chemotherapy. The CHOP therapy has improved DLBCL prognosis, where about $65 \%$ of DLBCL patients entered into complete remission; however, $30-40 \%$ of patients developed relapsed/refractory ( $R / R$ ) disease [29]. Recently, many therapies that have emerged in DLBCL include PD-L1/PD-1 inhibitors, but with a limited response [55]. It was shown that CD20+ cells might have a role in resistance to chemotherapy [26]. There remains no data regarding the PDL-1 and PD-1 expression in peripheral CD20 cells in DLBCL. Heterogeneity of PD-L1/PD-1 expression in DLBCL tumor cells needs to identify new markers for the prediction and diagnosis of DLBCL [56]. No previous studies were focused on analyzing PD-L1+CD20+ \% and PD-1+CD20+ \% within DLBCL.

This study identified PD-L1/PD-1 expression in peripheral CD20+ cells in DLBCL using flow cytometric analysis. Many studies had used the IHC method, but PD-L1 expression was not consistent owing to these assays being dependent on cutoff values, the specific type of antibodies, companies, and companion instruments used [38,57,58]. This study revealed that PDL-1/PD-1 expression in circulating CD20+ cells was highly significantly different from that in healthy volunteers. PD-L1+CD20+\% and PD-1+CD20+\% were greatly increased in newly diagnosed ones. Previously, it was suggested that PD-1+ B lymphocytes might reduce $\mathrm{T}$ cells expansion and that PD-L1 had a suppressive role orchestrated by PD-1+ B lymphocytes [59]. Xiao et al. [60] detected PD-1-expressing B lymphocytes with tumorigenic activity. Similar to this study, peripheral PD-1+CD20+ were rare in healthy controls [59].

Previously, PD-L1-expressing B cells were reported as a mechanism for humoral immunity suppression [61]. Previous reports showed that PD-L1 might inhibit the activation of B cells [62]. Brahmer et al. had suggested that PD-L1 antibodies therapy might relieve the PD-L1 inhibitory effect on B cells. Previous studies found that B lymphocytes suppress anti-tumor immune response [63].

After six cycles of CHOP therapy, CD20 \%, PD-L1+CD20+ \%, and PD-1+CD20+ \% were significantly lower in post-therapy patients than pre-therapy ones, suggesting that peripheral CD20 may have a role in detecting post-therapy DLBCL patients. The reason for this observation may be the reduction in the lymph node tumor and radiotherapy treatment. Eradicating PD-L1+ CD20+ or PD-1+ CD20 cells as therapy should be examined in DLBCL. Previous reports revealed that the expression level of PDL-1 positive rate and PD-1+ B cells was reduced significantly in complete remission [61,64]. The data revealed that peripheral CD20+ cells play a significant role in DLBCL pathogenesis and highlights the significance of lowering PD-L1+CD20+ \% and PD-1+CD20+ \% to overcome DLBCL.

Interestingly, the results revealed a statistically significant increase in PD-L1+CD20+ \% in post-therapy patients in comparison to healthy volunteers. Herbst et al. [65] had reported no significant correlation between efficacy of therapy and PD-L1 expression. However, post-therapy patients had a statistically insignificant difference between PD1 expression in peripheral CD20 cells and the healthy control group, which might be explained by the fact that patients could be benefitting from CHOP therapy in decreasing PD-1+ B+ percentages. Moreover, radiotherapy and tumor removal could help with the eradication of PD-1+CD20+ cells. This study involved DLBCL patients treated with CHOP chemotherapy which might affect CD20 cells and PD-1 but not PD-L1 expression in peripheral CD20 cells.

Upon correlating PDL-1 expression with laboratory quantitative variables, CD20+ and PDL-1+CD20+ showed a significant negative correlation with serum albumin in newly diagnosed DLBCL patients. These findings suggest that there are close relationships between PDL-1/PD-1 expression levels and the prognosis and severity of the disease. Additionally, CD20+ cells and PD-L1+CD20 cells are associated with serum total bilirubin. It was suggested that increased or altered expression of PDL-1 could cause self-tolerance disruption leading to autoimmunity, especially autoimmune liver disease [66]. These 
results supported that PD-L1 and CD20 expression might be important for DLBCL patients' identification with a higher risk of lymphoma progression.

The study revealed a highly significant positive association between PD-L1+CD20+\% and PD-1+CD20+ \% in DLBCL. The study suggested that both cells might be engaged in DLBCL pathogenesis. The mechanism is unknown, but it might need further study in the future.

The reported associations in this study supported the significant correlations between high PD-L1+CD20+ \%, PD-1+CD20 \%, and bad prognosis factors such as elevated LDH levels. These results were consistent with other studies [67]. This positive association suggested the importance of PD-1+CD20+ \% as a potential biomarker in DLBCL patients.

The data assumed highly significant correlations between high percentages of PD$1+C D 20+$ cells and splenomegaly. Extramedullary involvement and HSM may be signs of dissemination or severity of the disease, underscoring the importance of this mechanism for cancer progression and metastasis. These results supported that PD-1 expression in CD20 cells might be important for DLBCL patient identification with a high risk of lymphoma progression. In another study, expression of PD-1 was suggested to associate with a bad prognosis in DLBCL [68].

The study revealed that PD-L1+CD20+ \% and PD-1+CD20+\% were significantly increased in patients with advanced disease stages (Figure 3), assuming that these cells might act as indicators of DLBCL progression. Moreover, no significant changes in percentages of cells between stage I and stage II were observed, assuming that PD-L1+CD20+\% and PD-1+CD20+ \% may not have major roles at primary DLBCL stages. Previous reports have identified that PD-L1/PD-1 might be associated with DLBCL progression $[69,70]$. The study investigated PD-L1+CD20+ \% and PD-1+CD20+\% with bone marrow involvement and B symptoms and identified that expression of PD-L1/PD-1 in CD20+ cells was increased in DLBCL patients with these clinical symptoms (Figure 3). Previous reports revealed that B symptoms and bone marrow involvement indicate a poor prognosis of DLBCL [71]. The data indicate that PD-L1+CD20+ and PD-1+CD20+ cells might be involved in DLBCL prognosis. However, the mechanism of how these cells may affect the progression and the development of DLBCL remains unclear. Further studies are required.

PD-L1+CD20+ \% and PD-1+CD20+ \% were higher in the non-GCB type of DLBCL, compared with GCB-type, which had low percentages of PD-L1+CD20+ and PD-1+CD20+ cells. Previous studies have mentioned that the non-GCB DLBCL type had higher PD-L1 expression than the GCB DLBCL type [72-74]. In contrast, there were no significant differences regarding age and extranodal involvement in newly diagnosed DLBCL patients.

In this study, decreased PD-L1+CD20+ \% was associated significantly with the primary disease stages and GCB-DLBCL in post-therapy DLBCL patients. However, this was not statically significant for PD-1 expression of CD20 cells. This suggests that PD-L1+CD20+ cells can be used as a biomarker for disease severity and prognosis.

No previous studies used ROC curves to discuss the significance of PD-L1+CD20+\% and PD-1+CD20+\% in distinguishing between healthy controls and patients with DLBCL and discriminating newly diagnosed patients from healthy volunteers. In this study, the performance of the markers in differentiating DLBCL from normal controls was evaluated. PD-L1+CD20+ \% and PD-1+CD20+ \% improved the prediction of DLBCL patients. PD$\mathrm{L} 1+\mathrm{CD} 20+$ and PD-1+CD20+ cut-off values of $>1.1$ and $>1.2$ were successful in predicting DLBCL. The use of PD-L1+CD20+ \% improved the predictive performance (AUC = 1 versus 0.780 in CD20+ and 0.776 in PD-L1+CD20), with a sensitivity and specificity of $100 \%$ versus (77.50 and $63.16 \%$ ) for CD20+ \% and (75 and $73.68 \%$ ) for PD-1+CD20+ \%. The use of PD-L1+CD20+ percentages outperformed CD20+ and PD-1+CD20+ in discriminating DLBCL from normal controls. These data are vital as the PD-L1 cutoff applied for DLBCL (ranges from 5 to about 39\%) and this cutoff differs greatly [38,40]. Therefore, having an improved diagnostic marker for DLBCL needs a critical priority.

The AUC value of PD-L1+CD20+ for detecting newly diagnosed DLBCL from normal controls was also as high as 1.0 and was similar to PD-1+CD20+ with a cutoff value for 
PD-L1+CD20 $+>1.1$ and for of PD-1+CD20+ $>1.2$. The sensitivity and specificity of PD$\mathrm{L} 1+\mathrm{CD} 20+$ for differentiating pre-therapy DLBCL from healthy volunteers were $100 \%$ too. These findings reported that the diagnostic performance of PD-L1+CD20+ was superior to that of PD-1+CD20+ in diagnosing DLBCL.

According to this study, measuring the percentages of PD-L1+CD20+ cells might be a valuable diagnostic tool for the prediction and diagnosis of DLBCL. Based on these data, the study proposed that the use of flow cytometry for assessing PDL-1/PD-1 positive peripheral CD20 cells could help with the identification of DLBCL.

\section{Study Limitations}

PD-L1+CD20+ \% and PD-1+CD20 \% cells had not been assessed in tumor cells. However, Kleinovink et al. [75] had revealed that expression of PD-L1 in tumor cells could not identify a positive PD-1/PD-L1 inhibitors outcome. Moreover, future studies will follow up with the patients and use a variety of methods to assess the CD20 cell function in DLBCL patients. Follow-up for DLBCL patients was not performed. The correlations between PD-1/PD-L1 expression in CD20 cells and disease recurrence or overall survival were not assessed. Future studies will follow up with the patients to investigate these correlations.

\section{Conclusions}

The results revealed that circulating PD-L1+CD20+ and PD-1+CD20+ cells may represent a companion biomarker for DLBCL and may reflect the severity of DLBCL. Strategies targeting CD20 cells expressing PD-L1 or/and PD-1 may increase the efficacy of PD-L1/PD1 blockade immunotherapy in DLBCL. Circulating PD-L1+CD20+ cells are highly specific and sensitive for DLBCL diagnosis.

Supplementary Materials: The following supporting information can be downloaded at: https: / / www.mdpi.com/article/10.3390/antib11010015/s1, Table S1: Association of PD-L1+CD20+ \% and PD-1+CD20+ \% with the clinicopathological characteristics of pre-therapy DLBCL patients. Table S2: Association of PD-L1+CD20+ \% and PD- $1+C D 20+\%$ with the clinicopathological characteristics of post-therapy DLBCL patients.

Funding: The research received no external funding.

Institutional Review Board Statement: The study was conducted according to the guidelines of the Declaration of Helsinki. The study protocol and informed consent were approved by the Faculty of Medicine Ethics Committee of Minia University (Ref No.: 254).

Informed Consent Statement: Informed consent was obtained from all subjects involved in the study.

Data Availability Statement: The datasets generated during and/or analyzed during the current study are not publicly available but are available from the corresponding author on reasonable request.

Acknowledgments: The author thanks all technicians and participants in this study.

Conflicts of Interest: The author declares no conflict of interest.

\section{References}

1. Swerdlow, S.H.; Campo, E.; Harris, N.L.; Jaffe, E.S.; Pileri, S.A.; Stein, H.; Thiele, J. WHO Classification of Tumours of Haematopoietic and Lymphoid Tissues; Revised, 4th ed.; International Agency for Research on Cancer: Lyon, France, 2017; Volume 2, pp. 190-198.

2. Siegel, R.L.; Miller, K.D.; Jemal, A. Cancer statistics. CA Cancer J. Clin. 2017, 67, 7-30. [CrossRef] [PubMed]

3. Armitage, J.O.; Gascoyne, R.D.; Lunning, M.A.; Cavalli, R. Non-Hodgkin lymphoma. Lancet 2017, 390, 298-310.

4. Lodhi, N.; Tun, M.; Nagpal, P.; Inamdar, A.; Ayoub, N.M.; Siyam, N.; Oton-Gonzalez, L.; Gerona, A.; Morris, D.; Sandhu, R.; et al. Biomarkers and novel therapeutic approaches for diffuse large B-cell lymphoma in the era of precision medicine. Oncotarget 2020, 11, 4045-4073. [CrossRef] [PubMed]

5. $\quad$ Alizadeh, A.A.; Eisen, M.B.; Davis, R.E.; Ma, V.; Lossos, I.S.; Rosenwald, A.; Boldrick, J.C.; Sabet, H.; Tran, T.; Yu, X.; et al. Distinct types of diffuse large B-cell lymphoma identified by gene expression profiling. Nature 2000, 403, 503-511.

6. Read, J.A.; Koff, J.L.; Nastoupil, L.J.; Williams, J.N.; Cohen, J.B.; Flowers, C.R. Evaluating cell-of-origin subtype methods for predicting diffuse large B-cell lymphoma survival: A meta-analysis of gene expression profiling and immunohistochemistry algorithms. Clin. Lymphoma Myeloma Leuk. 2014, 14, 460-467. [CrossRef] 
7. McKelvey, E.M.; Gottlieb, J.A.; Wilson, H.E.; Haut, A.; Talley, R.W.; Stephens, R.; Lane, M.; Gamble, J.F.; Jones, S.E.; Grozea, P.N.; et al. Hydroxy daunomycin (Adriamycin) combination chemotherapy in malignant lymphoma. Cancer 1976, 38, 1484-1493. [CrossRef]

8. Pfreundschuh, M.; Kuhnt, E.; Trümper, L.; Osterborg, A.; Trneny, M.; Shepherd, L.; Gill, D.S.; Walewski, J.; Pettengell, R.; Jaeger, U.; et al. CHOP-like chemotherapy with or without rituximab in young patients with good-prognosis diffuse large-B-cell lymphoma: 6-year results of an open-label randomized study of the MabThera International Trial (MInT) Group. Lancet Oncol. 2011, 12, 1013-1022. [CrossRef]

9. Friedberg, J.W. Relapsed/refractory diffuse large B-cell lymphoma. Hematol. Am. Soc. Hematol. Educ. Program 2011, 2011, 498-505. [CrossRef] [PubMed]

10. Vital, E.M.; Dass, S.; Emery, P. B-cell depletion. In Rheumatology, 6th ed.; Hochberg, M.C., Silman, A.J., Smolen, J.S., Eds.; ScienceDirect: Philadelphia, PA, USA, 2015; pp. 472-478.

11. Middleton, O.; Wheadon, H.; Michie, A.M. Classical complement pathway. In Encyclopedia of Immunobiology; Ratcliffe, M.J.H., Ed.; Oxford Academic Press: New York, NY, USA, 2016; pp. 318-324.

12. Clark, E.A.; Shu, G.; Ledbetter, J.A. Role of the Bp35 cell surface polypeptide in human B-cell activation. Proc. Natl. Acad. Sci. USA 1985, 82, 1766-1770. [CrossRef]

13. Golay, J.T.; Clark, E.A.; Beverley, P.C. The CD20 (Bp35) antigen is involved in the activation of $B$ cells from the $\mathrm{G}_{0}$ to the $\mathrm{G}_{1}$ phase of the cell cycle. J. Immunol. 1985, 135, 3795-3801. [PubMed]

14. Huh, Y.O.; Keating, M.J.; Saffer, H.L.; Jilani, I.; Lerner, S.; Albitar, M. Higher Levels of Surface CD20 Expression on Circulating Lymphocytes Compared with Bone Marrow and Lymph Nodes in B-Cell Chronic Lymphocytic Leukemia. Am. J. Clin. Pathol. 2001, 116, 437-443. [CrossRef]

15. Küppers, R.; Engert, A.; Hansmann, M.L. Hodgkin lymphoma. J. Clin. Investig. 2012, 122, 3439-3447. [CrossRef] [PubMed]

16. Olejniczak, S.H.; Stewart, C.C.; Donohue, K.; Czuczman, M.S. A quantitative exploration of surface antigen expression in common B-cell malignancies using flow cytometry. Immunol. Investig. 2006, 35, 93-114. [CrossRef]

17. Stein, H.; Chan, J.K.C.; Warnke, R.A.; Gatter, K.C.; Chan, W.C.; Campo, E.; Jaffe, E.S. Diffuse large B-cell lymphoma, not otherwise specified. In WHO Classification of Tumors of Hematopoietic and Lymphoid Tissues; Swerdlow, S.H., Campo, E., Harris, N.L., Jaffe, E.S., Pileri, S.A., Stein, H., Thiele, J., Eds.; WHO: Geneva, Switzerland, 2008; pp. 233-237.

18. Castillo, J.J.; Chavez, J.C.; Hernandez-Ilizaliturri, F.J.; Montes-Moreno, S. CD20-negative diffuse large B-cell lymphomas: Biology and emerging therapeutic options. Expert Rev. Hematol. 2015, 8, 343-354. [CrossRef] [PubMed]

19. Montes-Moreno, S.; Montalban, C.; Piris, M.A. Large B-cell lymphomas with plasmablastic differentiation: A biological and therapeutic challenge. Leuk. Lymphoma 2012, 53, 185-194. [CrossRef]

20. His, E.D.; Lorsbach, R.B.; Fend, F.; Dogan, A. Plasmablastic lymphoma and related disorders. Am. J. Clin. Pathol. 2011, $136,183-194$.

21. Laurent, C.; Do, C.; Gascoyne, R.D.; Lamant, L.; Ysebaert, L.; Laurent, G.; Delsol, G.; Brousset, P. Anaplastic lymphoma kinasepositive diffuse large B-cell lymphoma: A rare clinicopathologic entity with poor prognosis. J. Clin. Oncol. 2009, 27, 4211-4216. [CrossRef]

22. Feugier, P.; Van Hoof, A.; Sebban, C.; Solal-Celigny, P.; Bouabdallah, R.; Fermé, C.; Christian, B.; Lepage, E.; Tilly, H.; Morschhauser, F.; et al. Long-term results of the R-CHOP study in the treatment of elderly patients with diffuse large B-cell lymphoma: A study by the Groupe d' Etude des Lymphomes de l' Adulte. J. Clin. Oncol. 2005, 23, 4117-4126. [CrossRef]

23. Pfreundschuh, M.; Trümper, L.; Osterborg, A.; Pettengell, R.; Trneny, M.; Imrie, K.; Ma, D.; Gill, D.; Walewski, J.; Zinzani, P.L.; et al International Trial Group: $\mathrm{CHOP}$-like chemotherapy plus rituximab versus $\mathrm{CHOP}$-like chemotherapy alone in young patients with good-prognosis diffuse large-B-cell lymphoma: A randomised controlled trial by the MabThera International Trial (MinT) Group. Lancet Oncol. 2006, 7, 379-391. [CrossRef]

24. Habermann, T.M.; Weller, E.A.; Morrison, V.A.; Gascoyne, R.D.; Cassileth, P.A.; Cohn, J.B.; Dakhil, S.R.; Woda, B.; Fisher, R.I.; Peterson, B.A.; et al. Rituximab-CHOP versus $\mathrm{CHOP}$ alone or with maintenance rituximab in older patients with diffuse large B-cell lymphoma. J. Clin. Oncol. 2006, 24, 3121-3127. [CrossRef] [PubMed]

25. Pfreundschuh, M.; Schubert, J.; Ziepert, M.; Schmits, R.; Mohren, M.; Lengfelder, E.; Reiser, M.; Nickenig, C.; Clemens, M.; Peter, N.; et al. German High-Grade Non-Hodgkin Lymphoma Study Group (DSHNHL): Six versus eight cycles of bi-weekly CHOP-14 with or without rituximab in elderly patients with aggressive CD20+ B-cell lymphomas: A randomized controlled trial (RICOVER-60). Lancet Oncol. 2008, 9, 105-116. [CrossRef]

26. Rassidakis, G.Z.; Medeiros, J.; Viviani, S.; Bonfante, V.; Nadali, G.P.; Vassilakopoulos, T.P.; Mesina, O.; Herling, M.; Angelopoulou, M.K.; Giardini, R.; et al. CD20 expression in Hodgkin and Reed-Sternberg cells of classical Hodgkin's disease: Associations with presenting features and clinical outcome. J. Clin. Oncol. 2002, 20, 1278-1287. [PubMed]

27. Cohen, Y.; Solal-Celigny, P.; Polliack, A. Rituximab therapy for follicular lymphoma: A comprehensive review of its efficacy as primary treatment, treatment for relapsed disease, retreatment, and maintenance. Haematologica 2003, 88, 811-823. [PubMed]

28. Coiffier, B. Rituximab and CHOP-like chemotherapy in good-prognosis diffuse large-B-cell lymphoma. Nat. Clin. Pract. Oncol. 2006, 3, 594-595. [CrossRef] [PubMed] 
29. Coiffier, B.; Thieblemont, C.; Van Den Neste, E.; Lepeu, G.; Plantier, I.; Castaigne, S.; Lefort, S.; Marit, G.; Macro, M.; Sebban, C.; et al. Long-term outcome of patients in the LNH-98.5 trial, the first randomized study comparing rituximab-CHOP to standard CHOP chemotherapy in DLBCL patients: A study by the Groupe d'Etudes des Lymphomes de l'Adulte. Blood 2010, 116, 2040-2045. [CrossRef] [PubMed]

30. Atchi, T.; Liu, D. Diagnosis and treatment of CD20 negative B cell lymphomas. Biomark Res. 2017, 16, 1-5.

31. Sanmamed, M.F.; Chen, L. Inducible expression of B7-H1 (PD-L1) and its selective role in tumor site immune modulation. Cancer J. 2004, 20, 256-261. [CrossRef] [PubMed]

32. Freeman, G.J.; Long, A.J.; Iwai, Y.; Bourque, K.; Chernova, T.; Nishimura, H.; Fitz, L.J.; Malenkovich, N.; Okazaki, T.; Byrne, M.C.; et al. Engagement of the PD-1 immunoinhibitory receptor by a novel B7 family member leads to negative regulation of lymphocyte activation. J. Exp. Med. 2000, 192, 1027-1034. [CrossRef] [PubMed]

33. Blank, C.; Gajewski, T.F.; Mackensen, A. Interaction of PD-L1 on tumor cells with PD-1 on tumor-specific T cells as a mechanism of immune evasion: Implications for tumor immunotherapy. Cancer Immunol. Immunother. 2005, 54, 307-314.

34. Sharpe, A.H.; Wherry, E.J.; Ahmed, R.; Freeman, G.J. The function of programmed cell death 1 and its ligands in regulating autoimmunity and infection. Nat. Immunol. 2007, 8, 239-245. [PubMed]

35. He, J.; Hu, Y.; Hu, M.; Li, B. Development of PD-1/PD-L1 pathway in tumor immune microenvironment and treatment for non-small cell lung cancer. Sci. Rep. 2015, 5, 13110.

36. Ishida, M.; Iwai, Y.; Tanaka, Y.; Okazaki, T.; Freeman, G.J.; Minato, N.; Honjo, T. Differential expression of PD-L1 and PD-L2, ligands for an inhibitory receptor PD-1, in the cells of lymphohematopoietic tissues. Immunol. Lett. 2002, 84, 57-62. [CrossRef]

37. Andorsky, D.J.; Yamada, R.E.; Said, J.; Pinkus, G.S.; Betting, D.J.; Timmerman, J.M. Programmed death-ligand 1 is expressed by non-Hodgkin lymphomas and inhibits the activity of tumor-associated T cells. Clin. Cancer. Res. 2011, 17, 4232-4244. [CrossRef] [PubMed]

38. Kiyasu, J.; Miyoshi, H.; Hirata, A.; Arakawa, F.; Ichikawa, A.; Niino, D.; Sugita, Y.; Yufu, Y.; Choi, I.; Abe, Y.; et al. Expression of programmed cell death ligand 1 is associated with poor overall survival in patients with diffuse large B-cell lymphoma. Blood 2015, 126, 2193-2201. [CrossRef] [PubMed]

39. Hu, L.Y.; Xu, X.L.; Rao, H.L.; Chen, J.; Lai, R.C.; Huang, H.Q.; Jiang, W.-Q.; Lin, T.-Y.; Xia, Z.-J.; Cai, Q.-Q. Expression and clinical value of programmed cell death-ligand 1 (PD-L1) in diffuse large B cell lymphoma: A retrospective study. Chin. J. Cancer 2017, 36, 94. [PubMed]

40. Fang, X.; Xiu, B.; Yang, Z.; Qiu, W.; Zhang, L.; Zhang, S.; Wu, Y.; Zhu, X.; Chen, X.; Xie, S.; et al. The expression and clinical relevance of PD-1, PD-L1, and TP63 in patients with diffuse large B-cell lymphoma. Medicine 2017, 96, e6398. [CrossRef] [PubMed]

41. Gatalica, Z.; Bilalovic, N.; Vranic, S.; Arguello, D.; Reddy, S.; Ghosh, N. PD-L1 and PD1 expression in lymphomas. Blood 2015, 126, 3899. [CrossRef]

42. Armand, P. Immune checkpoint blockade in hematologic malignancies. Blood 2015, 125, 3393-3400. [CrossRef] [PubMed]

43. Goodman, A.; Patel, S.P.; Kurzrock, R. PD-1-PD-L1 immune-checkpoint blockade in B-cell lymphomas. Nat. Rev. Clin. Oncol. 2016, 14, 203.

44. Non-Hodgkin Lymphoma Treatment; American Cancer Society: Kennesaw, GA, USA, 2019.

45. Swerdlow, S.H.; Campo, E.; Pileri, S.A.; Harris, N.L.; Stein, H.; Siebert, R.; Advani, R.; Ghielmini, M.; Salles, G.A.; Zelenetz, A.D.; et al. The 2016 Revision of the World Health Organization Classification of Lymphoid Neoplasms. Blood 2016, 127, 2375-2390. [PubMed]

46. Hans, C.P.; Weisenburger, D.D.; Greiner, T.C.; Gascoyne, R.D.; Delabie, J.; Ott, G.; Müller-Hermelink, H.K.; Campo, E.; Braziel, R.M.; Jaffe, E.S.; et al. Confirmation of the molecular classification of diffuse large B-cell lymphoma by immunohistochemistry using a tissue microarray. Blood 2004, 103, 275-282. [CrossRef] [PubMed]

47. Jang, R.W.; Caraiscos, V.B.; Swami, N.; Banerjee, S.; Mak, E.; Kaya, E.; Rodin, G.; Bryson, J.; Ridley, J.Z.; Le, L.W.; et al. Simple prognostic model for patients with advanced cancer based on performance status. J. Politics 2014, 10, e335-e341. [CrossRef] [PubMed]

48. Johnson, S.A.; Kumar, A.; Matasar, M.J.; Schöder, H.; Rademaker, J. Imaging for staging and response assessment in lymphoma. Radiology 2015, 276, 323-338. [CrossRef] [PubMed]

49. Brown Ja Dorfman, D.M.; Ma, F.-R.; Sullivan, E.L.; Munoz, O.; Wood, C.R.; Greenfield, E.A.; Freeman, G.J. Blockade of Programmed Death-1 Ligands on Dendritic Cells Enhances T Cell Activation and Cytokine Production. J. Immunol. 2003, 170, 1257. [CrossRef] [PubMed]

50. Nakamoto, N.; Cho, A.; Shaked, A.; Olthoff, K.; Valiga, M.E.; Kaminski, M.; Gostick, E.; Price, D.A.; Freeman, G.J.; Wherry, E.J.; et al. Synergistic Reversal of Intrahepatic HCV-Specific CD8 T Cell Exhaustion by Combined PD-1/CTLA-4 Blockade. PLoS Pathog. 2009, 5, e100031. [CrossRef] [PubMed]

51. Velu, V.; Kannanganat, S.; Ibegbu, C.; Chennareddi, L.; Villinger, F.; Freeman, G.J.; Ahmed, R.; Amara, R.R. Elevated expression levels of inhibitory receptor programmed death 1 on simian immunodeficiency virus-specific CD8 T cells during chronic infection but not after vaccination. J. Virol. 2007, 81, 5819. [CrossRef]

52. Li, H.; Pauza, C.D. CD25(+) Bcl6(low) T follicular helper cells provide help to maturing B cells in germinal centers of human tonsil. Eur. J. Immunol. 2015, 45, 298. [CrossRef] 
53. Polyak, M.J.; Deans, J.P. Alanine-170 and proline-172 are critical determinants for extracellular CD20 epitopes; heterogeneity in the fine specificity of CD20 monoclonal antibodies is defined by additional requirements imposed by both amino acid sequence and quaternary structure. Blood 2002, 99, 3256. [CrossRef] [PubMed]

54. Mack, C.L.; Tucker, R.M.; Sokol, R.J.; Karrer, F.M.; Kotzin, B.L.; Whitington, P.F.; Miller, S.D. Biliary atresia is associated with CD4+ Th1 cell-mediated portal tract inflammation. Pediatr. Res. 2004, 56, 79. [CrossRef] [PubMed]

55. Hawkes, E.A.; Grigg, A.; Chong, G. Programmed cell death-1 inhibition in lymphoma. Lancet Oncol. 2015, 16, e234-e245. [PubMed]

56. Madore, J.; Vilain, R.E.; Menzies, A.M.; Kakavand, H.; Wilmott, J.S.; Hyman, J.; Yearley, J.H.; Kefford, R.F.; Thompson, J.F.; Long, G.V.; et al. PD-L1 expression in melanoma shows marked heterogeneity within and between patients: Implications for anti-PD. 1/PD-L1 clinical trials. Pigment. Cell Melanoma Res. 2014, 28, 245-253. [CrossRef]

57. Liu, D.; Wang, S.; Bindeman, W. Clinical applications of PD-L1 bioassays for cancer immunotherapy. J. Hematol. Oncol. 2017, 10, 110. [CrossRef] [PubMed]

58. Diggs, L.P.; Hsueh, E.C. Utility of PD-L1 immunohistochemistry assays for predicting PD-1/PD-L1 inhibitor response. Biomark Res. 2017, 5, 12. [CrossRef] [PubMed]

59. Wang, X.; Wang, G.; Wang, Z.; Liu, B.; Han, N.; Li, J. PD-1-expressing B cells suppress CD4+ and CD8+ T cells via PD-1/PD-L1dependent pathway. Mol. Immunol. 2019, 109, 20-26. [CrossRef] [PubMed]

60. Xiao, X.; Lao, X.-M.; Chen, M.-M.; Liu, R.-X.; Wei, Y.; Ouyang, F.-Z. PD-1hi identifies a novel regulatory B-cell population in human hepatoma that promotes disease progression. Cancer Discov. 2016, 6, 546-559. [CrossRef] [PubMed]

61. Khan, A.R.; Hams, E.; Floudas, A.; Sparwasser, T.; Weaver, C.T.; Fallon, P.G. PDL1hi B cells are critical regulators of humoral immunity. Nat. Commun. 2015, 6, 5997. [CrossRef] [PubMed]

62. Howitt, B.E.; Shukla, S.A.; Sholl, L.M.; Ritterhouse, L.L.; Watkins, J.C.; Rodig, S.; Stover, E.; Strickland, K.C.; D’Andrea, A.D.; $\mathrm{Wu}, \mathrm{C}$.J. Association of polymerase e-mutated and microsatellite-instable endometrial cancers with neoantigen load, number of tumor-Infiltrating lymphocytes, and expression of PD-1 and PD-L1. JAMA Oncol. 2015, 1, 1319-1323. [CrossRef] [PubMed]

63. Brahmer, J.R.; Tykodi, S.S.; Chow, L.Q.; Hwu, W.J.; Topalian, S.L.; Hwu, P.; Drake, C.G.; Camacho, L.H.; Kauh, J.; Odunsi, K.; et al. Safety and activity of anti-PD-L1 antibody in patients with advanced cancer. N. Engl. J. Med. 2012, 366, 2455-2465. [CrossRef]

64. Ma, X.J.; Zhang, F.H.; Sun, L. Expression and significance of PDL-1, HSP90, and HSP90 $\alpha$ in serum of patients with acute leukemia. Zhongguo Shi Yan Xue Ye Xue Za Zhi 2017, 25, 1384-1389.

65. Herbst, R.S.; Baas, P.; Kim, D.W.; Felip, E.; Pérez-Gracia, J.L.; Han, J.Y.; Molina, J.; Kim, J.H.; Arvis, C.D.; Ahn, M.-J.; et al. Pembrolizumab versus docetaxel for previously treated, PD-L1-positive, advanced non-small-cell lung cancer (KEYNOTE-010): A randomized controlled trial. Lancet 2016, 387, 1540-1550. [CrossRef]

66. Mataki, N.; Kikuchi, K.; Kawai, T.; Higashiyama, M.; Okada, Y.; Kurihara, C.; Hokari, R.; Kawaguchi, A.; Nagao, S.; Kondo, T.; et al. Expression of PD-1, PD-L1, and PD-L2 in the liver in autoimmune liver diseases. Am. J. Gastroenterol. 2007, 102, 302-312. [CrossRef]

67. Fei, Y.; Yu, J.; Li, Y.; Li, L.; Zhou, S.; Zhang, T.; Li, L.; Qiu, L.; Meng, B.; Pan, Y.; et al. Plasma soluble PD-L1 and STAT3 predict the prognosis in diffuse large B cell lymphoma patients. J. Cancer 2020, 11, 7001-7008. [CrossRef]

68. Zhang, W.; Bai, J.F.; Zuo, M.-X.; Cao, X.-X.; Chen, M.; Zhang, Y.; Han, X.; Zhong, D.-R.; Zhou, D.-B. PD-1 expression on the surface of peripheral blood CD4(+) T cell and its association with the prognosis of patients with diffuse large B-cell lymphoma. Cancer Med. 2016, 5, 3077-3084. [CrossRef] [PubMed]

69. Gravelle, P.; Burroni, B.; Péricart, S.; Rossi, C.; Bezombes, C.; Tosolini, M.; Damotte, D.; Brousset, P.; Fournié, J.-J.; Laurent, C. Mechanisms of PD-1/PD-L1 expression and prognostic relevance in non-Hodgkin lymphoma: A summary of immunohistochemical studies. Oncotarget 2017, 8, 44960-44975. [CrossRef] [PubMed]

70. Xu-Monette, Z.Y.; Zhou, J.; Young, K.H. PD-1 expression and clinical PD-1 blockade in B-cell lymphomas. Blood 2018, 131, 68-83.

71. Montgomery, N.D.; Fedoriw, Y. Pathology consultation on intermediate-to-large B-cell lymphomas. Am. J. Clin. Pathol. 2014, 141, 305-317. [CrossRef] [PubMed]

72. Laurent, C.; Charmpi, K.; Gravelle, P.; Tosolini, M.; Franchet, C.; Ysebaert, L.; Brousset, P.; Bidaut, A.; Ycart, B.; Fournie, J.J. Several immune escape patterns in non-Hodgkin's lymphomas. Oncoimmunology 2015, 4, e1026530. [CrossRef] [PubMed]

73. Georgiou, K.; Chen, L.; Berglund, M.; Ren, W.; de Miranda, N.F.; Lisboa, S.; Fangazio, M.; Zhu, S.; Hou, Y.; Wu, K. Genetic basis of PD-L1 overexpression in diffuse large B-cell lymphomas. Blood 2016, 127, 3026-3034. [PubMed]

74. Siddiqi, I.N.; Thodima, V.; Friedman, J.; Violeta, A.; Tulpule, A.; Shaknovich, R.; Houldsworth, J. PD-L1 expression identifies high risk diffuse large B-cell lymphoma and is associated with several genomic markers. Blood 2016, 128, 153. [CrossRef]

75. Kleinovink, J.W.; Marijt, K.A.; Schoonderwoerd, M.J.A.; van Hall, T.; Ossendorp, F.; Fransen, M.F. PD-L1 expression on malignant cells is no prerequisite for checkpoint therapy. Oncoimmunology 2017, 6, e1294299. [CrossRef] 